*ak RMIS View/Frint Document Cover Sheet tow

This document was retrieved from the Documentation and Records Manaqement (DRM) ISEARCH System. It is intended for Information only and may not be the most recent or updated version. Contact a Document Service Center (see Hanford Info for locations) if you need additional retrieval information.

Accession \#: D196093633

Document \#: SD-W030-ATR-004

Title/Desc:

W-030 AY \& AZ TANK FARM COOLING \& MISC

INSTRUMENTATION [VENTILATION UPGRADES]

Pages: 54 


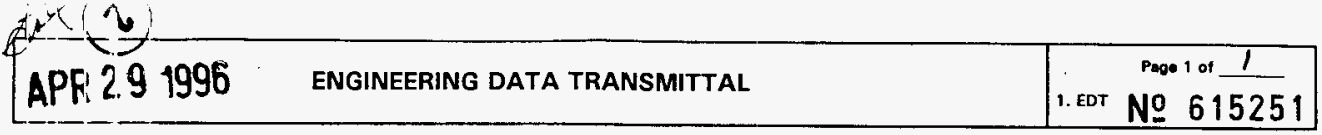

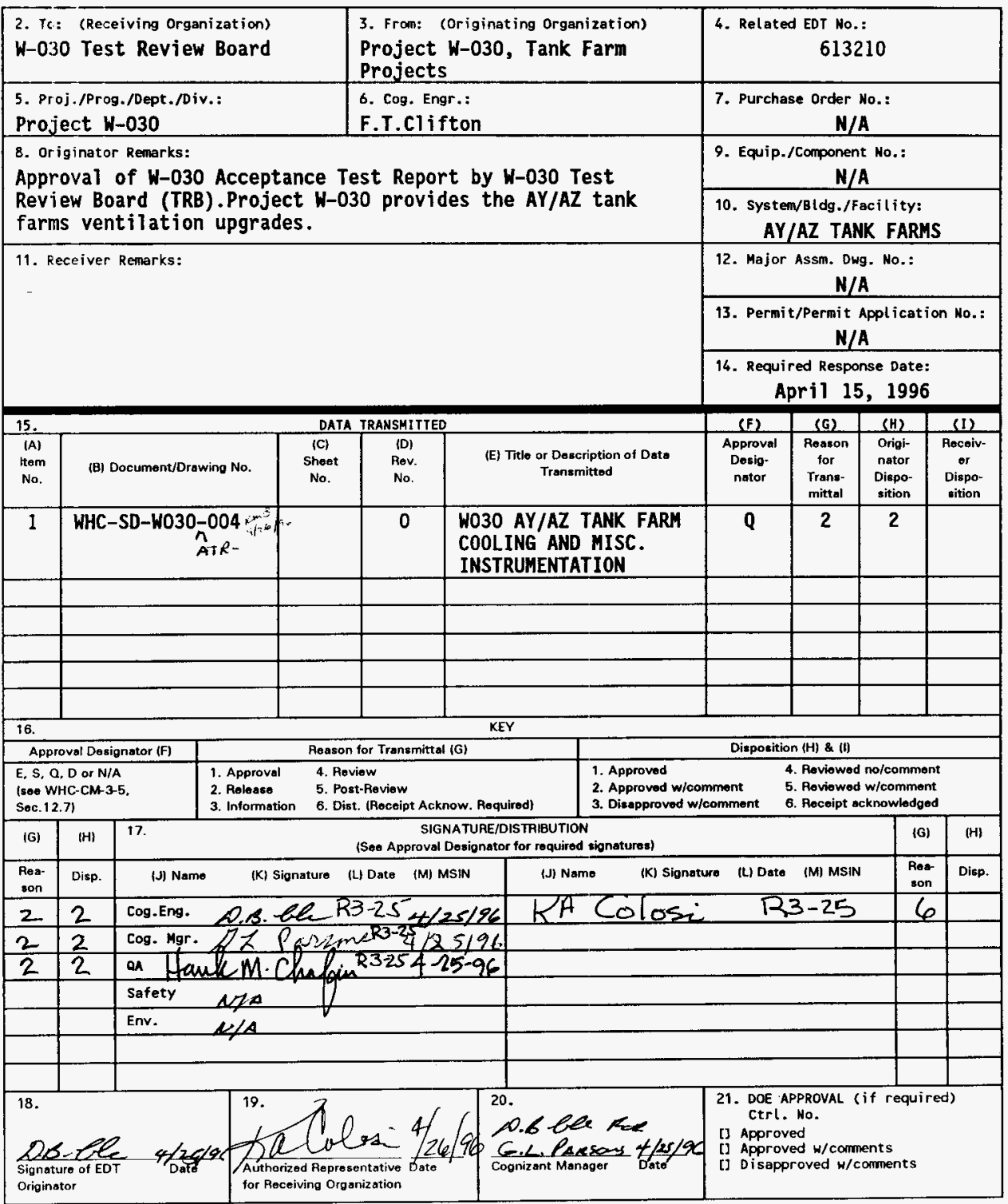




\title{
W030 AY/AZ TANK FARM COOLING AND MISCELLANEOUS INSTRUMENTATION
}

\author{
D.B.COLE
}

WHC, Richland, WA 99352

U.S. Department of Energy Contract DE-AC06-87RL10930

EDT/ECN: 615251

Org Code: 8K240

B\&R Code: EW3130010
UC: 2030

Charge Code: NK201 $\mathrm{Nota1}$ Pages: $39 \mathrm{~K} / \mathrm{KM} / 29 / 96$

Key Words: TEST, VENTILATION, INSTRUMENTATION, REPORT, W-030, STARTUP

Abstract: Acceptance test report for construction functional testing of Project $W-030$ cooling systems and related instrumentation. Project $W-030$ provides a ventilation upgrade for the four Aging Waste Facility tanks. The Tank Farm Cooling System consists of four forced draft cooling towers, a chilled water system, and associated controls.

TRADEMARK DISCLAIMER. Reference herein to any specific comercial product, process, or service by trade name, trademark, manufacturer, or otherwise, does not necessarily constitute or imply its endorsement, recomendation, or favoring by the United States Government or any agency thereof or its contractors or subcontractors.

Printed in the United States of America. To obtain copies of this document, contact: HHC/BCS Document Control Services, P.O. Box 1970, Mailstop H6-08, Richland WA 99352, Phone (509) 372-2420; Fax (509) 376-4989.
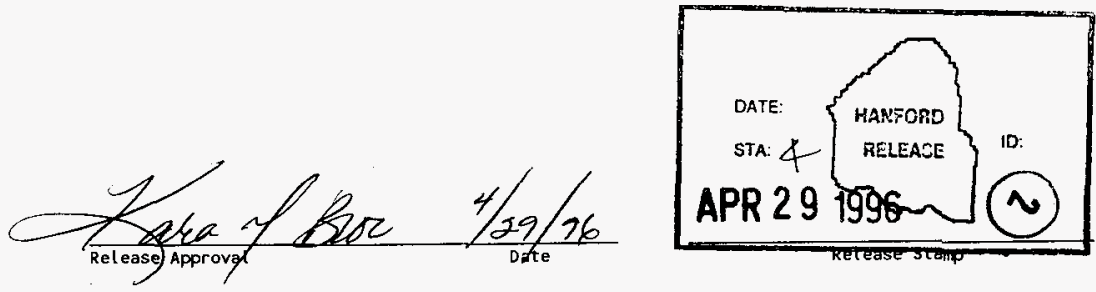

Approved for Public Release 


\section{ACCEPTANCE TEST PROCEDURE - TANK FARM AND MISC. INSTRUMENTATION}

FT Clifton

Westinghouse Hanford Company, Richland, WA 99352

U.S. Department of Energy Contract DE-ACO6-87RL10930

EDT/ECN: 613210

Org Code: 8K240

UC: 2030

Charge Code: NK201

B\&R Code: EW3130010 Total Pages: 37

Key Words: Test, Ventilation, instrumentation, acceptance, W-030, startup

Abstract: Acceptance Test Procedure for construction functional testing of Project $W-030$ cooling systems and related instrumentation. Project W-030 provides a ventilation upgrade for the four Aging Waste Facility tanks.

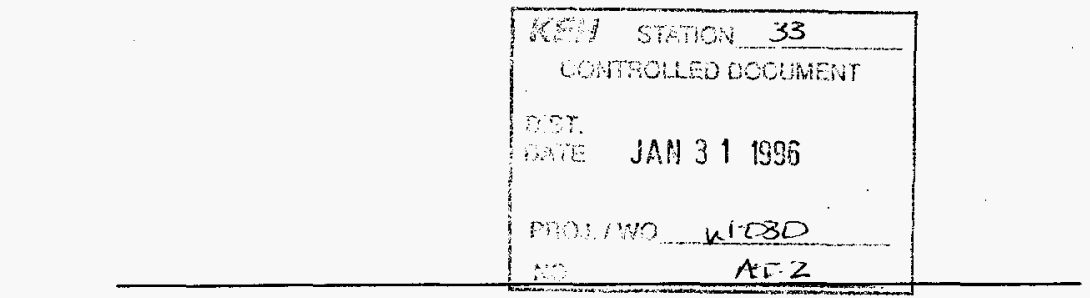

TRADEMARK DISCLAIMER. Reference herein to any specific conmercial product, process, or service by trade name, trademark, manufacturer, or otherwise, does not necessarily constifute or imply its endorsement, recommendation, or fuvoring by the United States Goverment or any agency thereof or its contractors or subcontractors.

Printed in the United states of Americs. To obtain copies of this document, contact: WHC/BCS Document Control Services, P.O. Box 1970, Mailstop H6-08, Rjehland HA 99352. Phone (509) 372-2420: Fax (509) 376-4989.
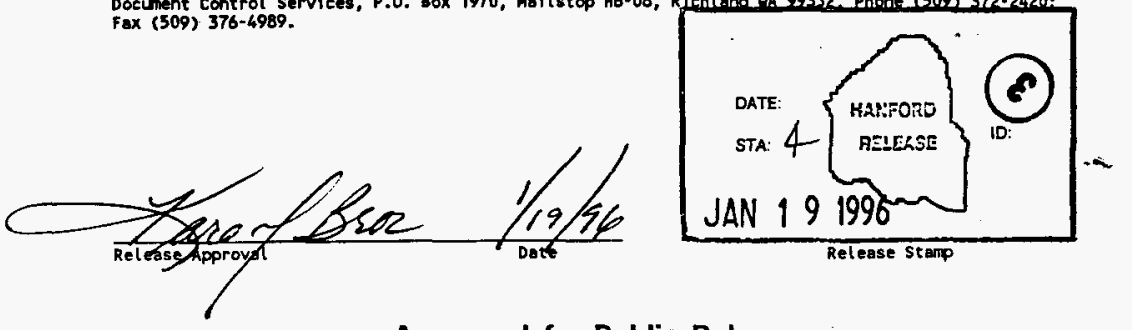

Approved for Public Release 
ACCEPTANCE TEST PROCEDURE' WHC-SD-W030-ATR-004

TEST TITLE AY/AZ Tank Farm Cooling and Miscellaneous Instrumentation

LOCATION AY/AZ Tank Farm

PROJECT NUMBER H-030

WORK ORDER P48738 and P48739

PROJECT TITLE Tank Farm Ventilation Upgrade

\section{Prepared By \\ ICF Kaiser Hanford Company \\ Richland, Washington \\ For Westinghouse Hanford Company \\ Subcontract WHC-380393}

PROCEDURE APPROVAL

ICF KAISER HANFORD COMPANY (ICF KH)

Mavk Q Fineduih $\frac{1-16-\%}{\text { Date }} \frac{\text { Qohert B Hoffmamn }}{\text { Technical Docutents }} \frac{1-16-96}{\text { Date }}$

Couthor

$\frac{1 / 16 / 96}{\text { Date }}$

C.D.

$\frac{1 / 17 / 46}{\text { Date }}$

$N / A$

Environmenta?

$-\frac{N / A}{\text { Quatity Engin }}$

Project Management

Date, Quality Engineering

Westinghouse Hanford Company (WHC)

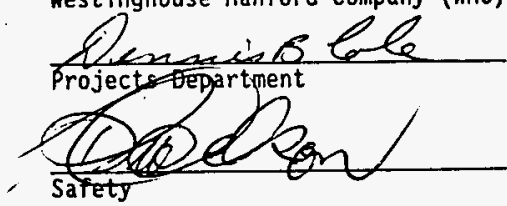

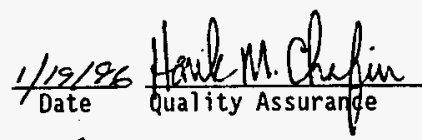

$\frac{1-18-\alpha}{\text { Date }}$

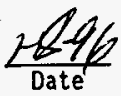

$\frac{M .0 . \text { Haddina }}{\text { Operations }}$

$\frac{1-19.96}{\text { Date }}$ 


\section{EXECUTION AND TEST APPROVAL}

EXECUTED BY

Test Director/Organization

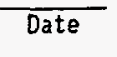

Test Operator/Organization

Date

Recorder/Organization

Date

WITNESSES

\section{Witness/Organization}

Witness/Organization

\section{Date Title III Inspector}

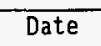

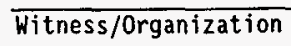

Date

Date

A-E APPROVAL

ICF Kaiser Hanford Company (ICF KH)

Without

exceptions
With exceptions resolved
With exceptions

outstanding

Acceptance Inspection

Date Design Engineer

Date

Project Manager

Date

TEST APPROVAL AND ACCEPTANCE

Westinghouse Hanford Company)

Without

With exceptions

resolved

With exceptions

exceptions outstanding

Projects Department

Date

Quality .Assurance

Date

Safety

Operations

Date 


\section{EXECUTION AND TEST APPROVAL}

EXECYTED BY

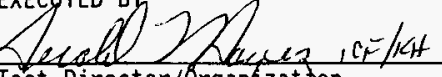

Test Director/organizatton

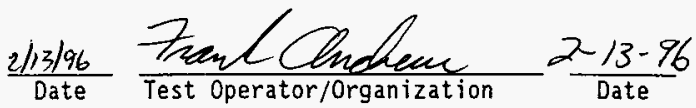

$\frac{B}{\text { Recorder/0rganization }}$ ICEKH $\frac{2.13 .96}{\text { Date }}$

WITNESSES

M. D. Aardeng efrods Witness/Organizatian

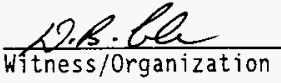

$\frac{4-15 q}{\text { Date }}$

$$
\text { Wit }
$$

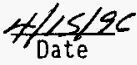

Witness/Organization

$\frac{2-13-96}{\text { Date }}$

Title III Inspector

Date

A-E APPROVAL

ICF Kaiser Hanford Company (ICF KH)
Without
With exceptions
resolved
With exceptions
exceptions

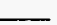
outstanding

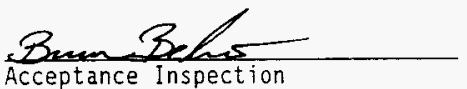

$\frac{3-28-96}{\text { Date }} \frac{\text { Monk a Firdind }}{\text { Design Engineer }}$

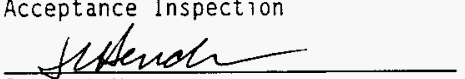

Project Manager
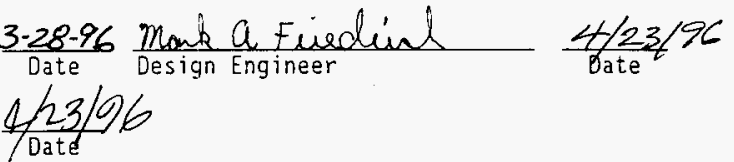

TEST APPROVAL AND ACCEPTANCE

Westinghouse Hanford Company)

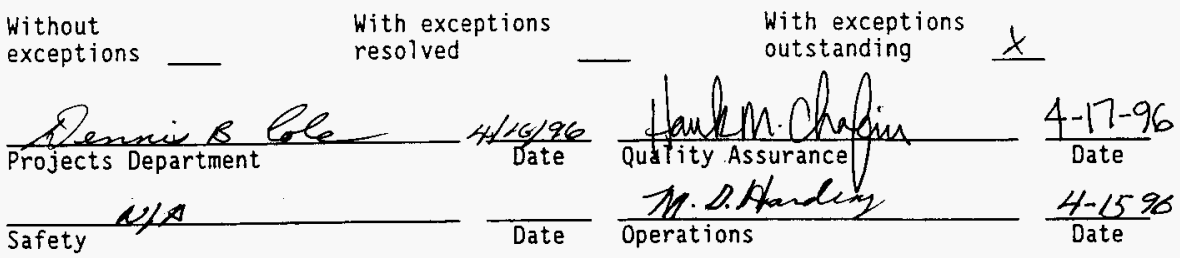


TITLE/PROCEDURE APPROVAL

EXECUTION AND TEST APPROVAL 2

TABLE OF CONTENTS 3

1 PURPOSE 4

2 REFERENCES

3 RESPONSIBILITIES - 5

4 CHANGE CONTROL 7

5 EXECUTION 8

6 EXCEPTIONS 8

7 PREREQUISITES, EQUIPMENT/INSTRUMENTS, AND ABBREVIATIONS 9

8 AY RECIRCULATING CONDENSATION COOLING TEST 11

9 AZ RECIRCULATING CONDENSATION COOLING TEST 23

10 AZCW VENTILATION CONDENSATION COOLING SYSTEM

EXCEPTION FORM

TEST EXCEPTION LOG 38

NOTE: At completion of test, enter pages added during performance of test to this Table of Contents. 
1 PURPOSE

This Acceptance Test Procedure (ATP) has been prepared in order to verify or demonstrate the following:

1.1 That the Contractor has performed the required calibration and wiring checks for all new instrumentation associated with:

1.1.1 Four packaged cooling towers and supply pumps.

1.1.2 One packaged process water chiller, condenser, and supply pumps.

1.2 Limited operational checks (including control devices) of:

1.2.1 Four packaged cooling towers and supply pumps.

1.2.2 One packaged process water chiller and supply pumps.

Local Control System testing will be accomplished by aligning the components as required for testing, actuating the local control switches, and verifying that the control signal is received at the component circuit breaker or motor starter. Manufacturer's representative will be consulted prior to energizing packaged equipment.

2 REFERENCES

2.1 DRAWINGS

H-2-131067, Sh 1, Rev 0 $\mathrm{H}-2-131068$, Sh 1, Rev 0 H-2-131069, Sh 1, Rev 0 $\mathrm{H}-2-131070$, Sh 1, Rev 0 $\mathrm{H}-2-131071$, Sh 1, Rev 0 $\mathrm{H}-2-131357$, Sh 1, Rev 0 $\mathrm{H}-2-131366$, Sh 1, Rev 0 H-2-131366, Sh 2, Rev 0 H-2-131366, Sh 3, Rev 0 H-2-131366, Sh 4, Rev 0 H-2-131366, Sh 5, Rev 0 $\mathrm{H}-2-131366$, Sh 6, Rev 0 H-2-131366, Sh 7, Rev 0
P\&ID AY10lEW Recirc Cond Cooling P\&ID AYI02EW Recirc Cond Cooling P\&ID AZ101EW Recirc Cond Cooling P\&ID AZ102EW Recirc Cond Cooling P\&ID AZCW Vent Cond Cooling Sys Electrical Yard Plan \& General Notes Electrical Elementary Diagram Recirc Bldg AY-101 \& AY-102

Electrical Elementary Diagram Recirc Bldg AZ-101 \& AZ-102

Electrical Elementary Diagram Evap TWr AY-101

Electrical Elementary Diagram Evap Twr AY-102

Electrical Elementary Diagram Evap Twr AZ-101

Electrical Elementary Diagram Evap Twr AZ-102

Electrical Elementary Diagram Chiller Pad 
2.2 SPECIFICATIONS

W-030-C3, Rev. 0

2.3 VENDOR INFORMATION (VI)

VJ-22525

3 RESPONSIBILITIES

3.1 GENERAL

Each company or organization participating in this ATP will designate personnel to assume the responsibilities and duties as defined herein for their respective roles. The designees shall become familiar with this ATP and the systems involved to the extent that they can perform their assigned duties.

3.2 WHC PROJECT ENGINEER

3.2.1 Designates a Test Director.

3.2.2 Coordinates testing with 200-East Tank Farms Operations.

3.2.3 Acts as liaison between the participants in acceptance testing.

3.2.4 Distributes the approved testing schedule before start of testing.

3.2.5 Schedules and conducts a pretest kickoff meeting with test participants when necessary.

3.2.6. Notifies the persons supporting the test 2 days before the start of testing.

3.2.7 Schedules a dry run when necessary.

3.2.8 Notifies concerned parties when a change is made in the testing schedule.

3.2.9 Signs Execution and Test Approval page when test is approved and accepted.

3.2.10 Takes necessary action to clear exceptions to the test.

3.2.11 Signs Exception Form when exception has been resolved.

3.2.12 Provides a distribution list for the approved and accepted ATP.

3.3 TEST DIRECTOR

3.3.1 Coordinates and directs acceptance testing.

3.3.2 Confirms that field testing and inspection of the system or portion of the system to be tested has been completed. 
3.3.3 Stops any test which, in his or her judgment, may cause damage to the system until the problem has been resolved.

3.3.4 After verifying there is no adverse impact, may alter the sequence in which systems or subsystems are tested.

3.3.5 Ensures that required environmental conditions are maintained.

3.3.6 If a test is to be suspended for a period of time, ensures that the system is left in a safe mode.

3.3.7 Before restarting suspended test, reverifies the test prerequisites.

3.3.8 Initiates Engineering Change Notices (ECNs) to document required changes to the ATP.

3.3.9 Reviews recorded data, discrepancies, and exceptions.

3.3.10 Obtains information or changes necessary to clear or resolve objections during the performance of the test.

3.3.11 Signs Execution and Test Approval page when test has been performed.

3.3.12 Signs Exception Form when exception has been resolved.

3.3.13 Obtains required signatures on the ATP Master prior to reproduction and distribution.

3.4 WITNESSES (Provided by Participating Organizations. One witness shall be a Title III acceptance inspector.)

3.4.1 Witness the tests.

3.4.2 Review results of testing.

3.4.3 Assist the Test Director when requested.

3.4.4 Sign Execution and Test Approval page when test has been performed.

3.4.5 Sign Exception Form when exception has been resolved.

3.5 RECORDER (Provided by ICF KH)

3.5.1 Prepares a Field copy from the ATP Master.

3.5.2 Records names of all designated personnel on Field copy of ATP prior to start of testing.

3.5.3 Records test instrument identification numbers and calibration expiration dates, as required.

3.5.4 Initials and dates every test step on the Field copy as it is completed next to the step number or on a data sheet, when provided. Records test data. On data sheets where there is not room for both the initial and date, date may be entered at bottom of column. 
3.5.5 Records objections and exceptions on an Exception form. Uses additional Exception forms as needed. Notifies the Test Director at time the objection is made.

3.5.6 Signs Execution and Test Approval page when test has been performed.

3.5.7 After test is finished, assigns alpha numeric page numbers to added data sheets and Exception forms. Records page numbers in the Table of Contents.

3.5.8 Transfers Field copy entries for each step to the Master in ink or type, signs, and dates. Transmits the completed Master to the Test Director for approval signature routing. Transmits the Field copy to Construction Document Control for inclusion in the official project file.

3.5.9 Signs Exception Form when exception has been resolved and transmits to Test Director.

3.6 TEST OPERATOR

3.6.1 Performs test under direction of the Test Director.

3.6.2 Provides Tabor, equipment, and test instruments required for performing tests which have not been designated as being provided by others.

3.6.3 Requests in writing from the Test Director those services, materials, or equipment that have been designated as being supplied by others.

3.6.4 Confirms that all equipment required for performing test will be available at the start of testing.

3.6.5 Signs the Execution and Test Approval page.

3.7 A-E ACCEPTANCE INSPECTION, DESIGN ENGINEER, AND PROJECT MANAGER

3.7.1 Evaluate results.

3.7.2 Sign for A-E Approval on Execution and Test Approval page.

Test procedure editorial changes required during testing may be accommodated as exceptions in the released ATP and Test Report, if the changes do not affect operating facility safety, function, or performance and do not compromise or influence test data. Requirement changes, changes to acceptance criteria, or changes to Danger, Caution, Special Precautions, or other safety or environmental instructions must be processed on ECNs in accordance with company procedures, and if a need for such a change is discovered in the course of running the test, the test shall be stopped unti] the ECN is approved. However, this does not prevent the running of another portion of the test unaffected by the change. 
5.1 OCCUPATIONAL SAFETY AND HEALTH

Individuals shall carry out their assigned work in a safe manner to protect themselves and others from undue hazards and to prevent damage to property and environment. Facility line managers shall assure the safety of activities within their areas to prevent injury, property damage, or interruption of operation. Performance of test activities shall always include safety and health aspects.

\subsection{PERFORMANCE}

\subsubsection{Conduct testing in accordance with ICF KH Procedure CON $\mathbf{3 . 5}$ (Performance and Recording of Acceptance Test Procedures).}

5.2.2 Perform test following the steps and requirements of this procedure.

\section{EXCEPTIONS}

6.1 GENERAL

Exceptions to the required test results are sequentially numbered and recorded on individual Exception forms. This enables case-by-case resolution and approval of each exception.

Errors/exceptions in the ATP itself shall NOT be processed as test exceptions (see Section 4 CHANGE CONTROL).

\subsection{RECOROING}

6.2.1 Number each exception sequentially as it occurs and record it on an Exception Form (KEH-428), sample appended.

6.2.2 Enter name and organization of objecting party for each exception.

6.2.3 Enter planned action to resolve each exception when such determination is made.

\subsection{RETEST/RESOLUTION}

Record the action taken to resolve each exception. Action taken may not be the same as planned action.
6.3 .1
When action taken results in an acceptable retest, sign and date Retest Execution and Acceptance section of the Exception Form.

\subsubsection{When action taken does not involve an acceptable retest, strike out} the Retest Execution and Acceptance section of the Exception Form. 


\subsection{APPROVAL AND ACCEPTANCE}

The customer provides final approval and acceptance of exceptions by checking one of the following on Exception Form:

6.4.J Retest Approved and Accepted: Applicable when Retest Execution and Acceptance section is completed.

6.4.2 Exception Accepted-As-Is: Requires detailed explanation.

6.4.3 Other: Requires detailed explanation.

The customer signs and dates the Exception form and obtains other customer internal approvals, if required.

\section{- 6.5 DISTRIBUTION}

A copy of the approved Exception Form is distributed to each participant. The signed original is attached to the ATP Master.

7 PREREQUISITES, EQUIPMENT/INSTRUMENTS, AND ABBREVIATIONS

7.1 PREREQUISITES

The following conditions shall exist at start of testing for that portion of the system being tested.

$38222-967.1 .1$ The recirculating condensation cooling systems have been inspected for compliance with construction documents.

B3 2.27.967.1.2 The AZCW ventilation condensation cooling system has been inspected for compliance with construction documents.

B3227.96 7.1.3 Reference documents (including this ATP) have been verified for correct revision number and outstanding ECNs.

B32.27.967.1.4 A Job Safety Analysis (JSA) has been prepared, read and signed, and a Prejob Safety Meeting has been conducted.

332.27 .967 .1 .5 A prejob walkdown of systems being tested has been conducted.

B82.27.967.1.6 Test instruments have a valid calibration stamp attached. Test instrument identification numbers and calibration expiration dates have been recorded in Para 7.2.

B 2-27-967.1.7 $120 \mathrm{~V}$ ac power is available. See Drawing H-2-131366, Sh 1 and 2.

B32.37967.1.8 Ice and hot water are available.

8B22796 7.1.9 Verification of required testing (meggering and continuity checks of all associated power cables and instrument and control cables) has been completed.

$\frac{B 3 \sim / A}{2.27 .96} 7.1 .10$ RWP has been approved by WHC Operations if required. 


\subsection{EQUIPMENT/INSTRUMENTS}

Supplied by Test Operator unless otherwise noted.

7.2.1 Digital Multimeter (DMM): 4-1/2 digit or better $0.5 \%$ minimum accuracy (ac volts).

Manufacturer Eluke Model No. 83 Serial No. 61200721

Calibration Date 12.21 .95 Expiration Date 12.21 .96 Delete $2 x^{ \pm 6}$

7.2 .2 Process Instrument Eatibrator (PIC): Output-4-20-mA, O-5 V, input 4-20-mA, $0-5-V$, -aceuraey \pm 0.01 mIA, $0.1+1$.

Hanufacturer ____ Modet No.______ Sertat No.

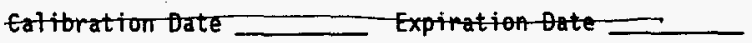

7.2.3 Container: To hold water for leak or level detector tests 4-inch. depth.

7.2.4 Thermometer.

7.2.5 Shorting Switches. 
This test will demonstrate the integrity of the instruments and equipment associated with the tank recirculating condensation cooling systems located at the AY evaporator pad. (Reference Drawings H-2-131067, Sh 1, H-2-131068, Sh l, and $\mathrm{H}-2-131357$, Sh 1)

8.1 FLUID COOLER SPRAY PUMP AY101-EW-SP-1 (Reference Drawing H-2-131366, Sh 3)

$B B 2-27-96$ 8.1.1 Verify that the disconnect switch to Fluid Cooler UIC-AY101EWT-1 is OPEN or OFF.

33 2.27.96 8.1.2 Verify that Spray Pump Handswitch HS-AY101EWSP-1A is in the SFOP- off position.

$B 32.27-96$ 8.1.3 Verify that Fluid Cooler Fan Handswitch HS-AY101EWT-1Al is in the sTop position.

B3.27.96 8.1.4 Verify that Pan Heater Handswitch HS-AY101EWT-1A2 is in the OFF position.

3.27.96 8.1.5 Verify that Damper Actuator Handswitch HS-AY101EWT-1A3 is in the AUTO position.

33 2.27.96 8.1.6 Verify that sump water make-up Isolation Valve HV-AYI0lRW-1 is CLOSED.

2.27.96 8.1.7 Verify that the spray pump sump is dry or water level is below the LSL-AYIOIEWT- 1 level probes.

$3 B 3.4 .96$ 8.1.8 Sot timer of fan on Delay Retay-2MS, to zo-seconds at control panel UIE-AYPOIEWT-1.

3B.2.27.96 8.1.9 Disconnect Motor Leads AY101EWT1-1T1, AY101EWT1-1T2, and AY101EWT1-1T3 from spray pump.

B82.27.96 8.1.10 Disconnect Power Leads AY101EWT1-3T1, AY101EWT1-3T2, and AY101EWT1-3T3 from pan heater.

BB 2.27.96 8.1.11 Install shorting switches at UIC-AY101EWT-1 between ILC level probe terminals as follows:

B82.27.26 8.1.11.1 Terminals "G" and "H," Switch "H" in the ON or CLOSED position.

38 2.27.96 8.1.11.2 Terminals "G" and "L," Switch "L" in the ON or CLOSED position.

BB 2.27.9C 8.1.11.3 Terminals " $G$ " and LLCO, Switch LLCO in the ON or CLOSED position.

NOTE: Shorting switches to remain in place until all tests associated with Fluid Cooler UIC-AYIOIEWT-1 have been completed.

Defte EcN 198

8.1.12_Connect a ONHA between UIC-AY10IEWF-1-Ferminals- 2 and-4.

$382.27-96$ 8.1. 312 CLOSE disconnect switch (see Step 8.1.1).

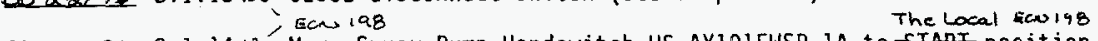

BB2.27-96 8.1. $\$ 413^{\prime}$ Move Spray Pump Handswitch HS-AY101EWSP-1A to-STARF position. 
contactor 1.MS closes Einsiag

BB2.22.96 8.11514 Verify AlP-reads tine-rottage-(120-tac nominait).

18 Verify contactor $1 \mathrm{~ms}$ opens $5 \mathrm{CN} 198$

2.27-96 8.1.16 Verify spray-ptimp-metor-starter-is 0 .

28 2.27.96 8.1 7716 Move Spray Pump Handswitch HS-AY101EWSP-1A the off exw198

- IA to STOP- position.

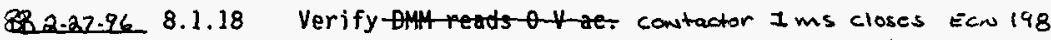

88 2-27-96 8.2.19-Vexify-spray pump-motor starter is 0ff: Delete Eun 198

283 2.2.96 8.1,2017 Move Spray Pump Handswitch HS-AY101EWSP-1A to START position.

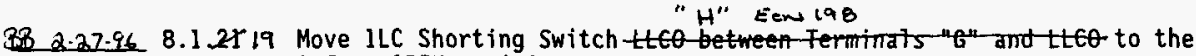

BB 2.27.96 8.1.20 OFF or Verify contactor 1 ms remains closed Ecu 198

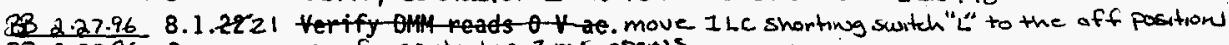

$38.2 .27-96-8 \cdot 1.22$

$83+2.27 .96$ 8.1.23

Verify contactor 1 ms opens

Return ILC Shorting Switch ttef to oN or EtOSED position.

832.27 .96 8.1.24 Verify

832.27 .96 move 1 LC shorting suritch "H" to the on positions Eaw 198

2.27.96 8.1.2528 Open disconnect switch. (see step 8.1.12)

38.2 .27 .96 8.1.27 muve spray pump humaswitch HS.AyiolEWSP.1A to the off position

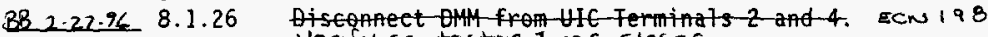

8.2 FLUID COOLER FAN HS-AY101EWT-IAI (Reference Drawing H-2-131366, Sh 3)

38 2.27.96 8.2.1 Verify that the disconnect switch to Fluid Cooler UIC-AY101EWT-1 is. OPEN or OFF.

3B 2.27.96 8.2.2 Verify that Spray Pump Handswitch HS-AY101EWSP-1A is in the ffOP-Ẽs 198 position.

22.276 8.2.3 Verify that Fluid Cooler Fan Handswitch HS-AY101EWT-1AI is in the offepsition.

$\$ 3$ 2.27-96 8.2.4 Verify that Pan Heater Handswitch HS-AY101EWT-1A2 is in the OFF position.

33 2.27-96 8.2.5 Verify that Damper Actuator Handswitch HS-AY101EWT-1A3 is in the AUTO position.

$B B$ 2.27.96 8.2.6 Verify that sump water make-up Isolation Valve HV-AYI01RW-1 is CLOSED.

383.4.26 8.2.7 Set-imer of fanion-Be7ay-Rolay-2MS, to-20-seconds at fontrol Panet UIC-AHIOHEWI-I:

2.27.96 8.2.8 Set in let fan damper temperature controller range indicator at $60^{\circ} \mathrm{F}$ using the set point adjusting knob on top of the controller.

38.2 .27 .96 8.2.9 Set inlet fan damper temperature controller throttling range to minimum position using the adjusting screw next to the set point adjustment knob. 
$332.27-96 \quad 8.2 .10$

Remove in let damper temperature element from thermowell and place temperature element in container of $75{ }^{\circ} \mathrm{F}$ or greater, water. 82.227 .968 .2 .12 mose spray Pump hawd switch HS-AYIOLEWSP -IA to the Locul positions

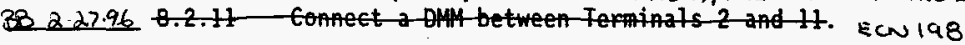

2.27.96 8.2.+211 CLOSE disconnect switch (see Step 8.2.1).

2.27.96 8.2.13 Move Cooling Fan Handswitch HS-AY101EWT-1A1 to LOCAAF position.

\section{That contactor $2 \mathrm{~ms}$ closes ECN 198}

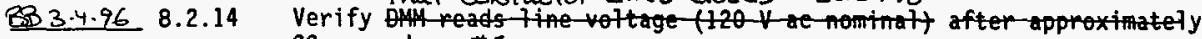
zo seends. Ex 1

3.27.96 8.2.15 Verify cooling fan motor is rotating.

2.27.96 8.2.16 Verify that inlet fan damper position indicator is in the OPEN

position. Ecinlag

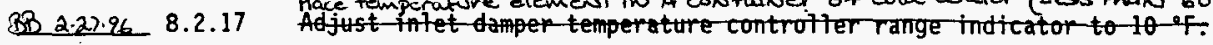

2827.96 8.2.18 Verify that inlet fan damper position indicator moves to the CLOSED position.

382.22 .96 8.2.19 Verify rens

2.27-96 8.2.20 Verify cooling fan motor stops rotating.

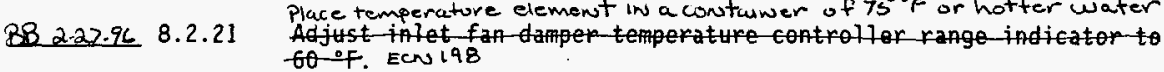

38 2.27.96 8.2.22 Verify that inlet fan damper position indicator is in the OPEN position.

38 2-27.96 8.2.23 Verify voltagen contactor $2 \mathrm{~ms}$ closcs

2.27.96 8.2.24 Move Fan Control Handswitch HS-AY101EWT-1Al to the off POP position.

2.27.96 8.2.25 Verify O OV Contactor $2 \mathrm{~ms}$ opens

2.27 .96 8.2.26 OPEN discannect switch. Ecen 198
Move spray pump hawdswitch to the off position

2.27.96 8.2.27 Bisconnet DMM from IIC Terminals-2 and 11

23 2.27.96 8.2.28 Remove in let fan damper temperature element from container of water, dry element, and reinstall element in thermowell.

8.3 FLUID COOLER PAN HEATERS (Reference Drawing H-2-131366, Sh 3)

38 2.27.96 8.3.1 Verify disconnect switch of fluid cooler is OPEN or OFF.

2.27.96 8.3.2 Verify that Spray Pump Handswitch HS-AY101EWSP-1A is in the STOP-off position.

ecus 198

32.27.96 8.3.3 Verify that Sump Water Make-up Isolation Valve HV-AYlolRW-1 is CLOSED. 
382.27 .96 8.3.4 Verify that the spray pump sump is dry or water level is below the LSL-AYIOIEWT-1 level probes.

33 3.4.96 8.3.5 Remove cover of pan heater thermostat housing and adjust thermostat to mimum temperature setting (150-degrees).

8.3.6_Connect-a Aly between-Controt Panel Ferminals 2 and-20.

2.27 .96 8.3. 76 CLOSE disconnect switch.

83237.968 .3 .87 Move the heater control handswitch to the on position.

$382.27 .96 \quad 8.3 .98$ Verify contactor $1 \mathrm{C}$ closes Ecn 198

28227.96 8.3.104 Move "1LC" Switch "LLCO" to the OFF or OPEN position.

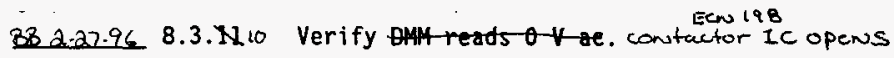

382.27 .968 .3 .121 " Move "ILC" Switch "LLCO" to the ON or CLOSED position.

BB2.27.9L 8.3. 1312 Verify AMH4-reds tine voltage. constactor 148 closes

$33.4 .96-3.1413$ Adjust pan heater thermostat to maximum ex=3

332.27-96 8.3.15 14 Verify DAll-reads-0 V at. Contactor 16 opens

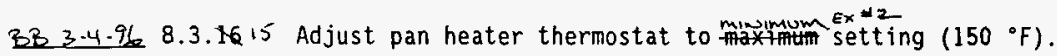

3B227.96 8.3.1716 Verify AMA peads tine-voltage. contactor 16 closes

$B B 2.27 .96$ 8.3.1817 Move heater control handswitch to the OFF position.

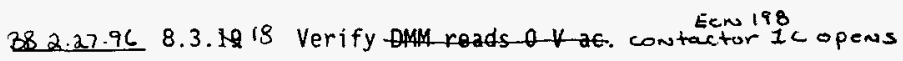

382.27 .968 .3 .8014 OPEN disconnect switch.

$=$ - 8.3.21_ Oisconnect OHAt-Delete Ecw 198

332.27 .96 8.3.22 20 Adjust pan heater thermostat to $40^{\circ} \mathrm{F}$ setting and install thermostat housing cover.

8.4 FLUID COOLER MAKE-UP WATER SOLENOID VALVE EV-AY10IEWT-1Al (Reference Drawing H-2-131366, Sh 3)

3827.96 8.4.1 Verify that the disconnect switch to fluid Cooler UIC-AY101EWT-1 is OPEN or OFF.

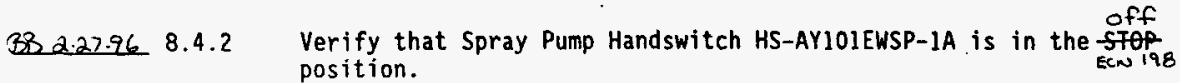

38 8.27-96 8.4.3 Verify that Sump Water Make-up Isolation Valve HV-AY101RW-1 is CLOSED.

38 2.27-96 8.4.4 Verify that the spray pump sump is dry or the water level is below the LSL-AYIOIEWT-1 level probes.

W030004.SP. 1232 
38.27 .968 .4 .5

$28.27-968.4 .6$

32.27 .968 .4 .7

2.27 .968 .4 .8

2.27.96 8.4.9

$3 B 2.27 .968 .4 .10$

$B B 2.27-968.4 .11$

2.27.96 8.4.12

$28.27 .96-8.4 .13$

$38 \quad 2.27 .96 \quad 8.4 .14$

$2.27 .96 \quad 8.4 .15$

$38.27 .96 \quad 8.4 .16$

$3 B 2.22 .96 \quad 8.4 .17$

882.27 .968 .4 .18
CLOSE disconnect switch (see Step 8.4.1).

Verify water make-up Solenoid Valve EV-AY101EWT-1AI is DE-ENERGIZED.

Move ILC Shorting Switch "H" to the OFF or OPEN position.

Verify water make-up Solenoid Valve EV-AYI01EWT-1Al is still DE-ENERGIZED.

Move ILC Shorting Switch "L" to the OFF or OPEN position.

Verify water make-up solenoid valve is ENERGIZED (Shorting Switch " $L$ " must remain OFF or OPEN for at least 6 seconds before ILC energizes the valve).

Move ILC Sharting Switch "L" to the ON or CLOSED position.

Verify water make-up solenoid valve is still ENERGIZED.

Move ILC Shorting Switch "H" to the ON or CLOSED position.

Verify water make-up solenoid valve is DE-ENERGIZED (Shorting Switch " $H$ " must remain ON or CLOSED for at least 6 seconds before ILC DE-ENERGIZES the valve).

OPEN disconnect switch (see Step 8.4.1).

Remove shorting switches at UIC-AY101EWT-I between ILC level probe.

Reconnect Motor Leads AY101EWT1-1T1, AY101EWT1-1T2, and AY101EWT1-1T3 to spray pump (see Step 8.1.9).

Reconnect Power Leads AY101EWT1-3T1, AY101EWT1-3T2, and AY101EWT1-3T3 to pan heater (see Step 8.1.10).

8.5 RECIRCULATION PUMP AYIOl-EH-P-IA (Reference Drawing H-2-131366, Sh 3)

88 2.27-96 8.5.1 Verify that the disconnect switch to Recirculation Pump AY10I-EW-P-1A is OPEN or OFF.

$B B 227.96$ 8.5.2 Disconnect Motor Leads AY101EWP1A-T1, AY101EWP1A-T2, and AY101EWPIA-T3 from Recirculation Pump AY101-EW-P-IA.

38 2.27.96 8.5. 34 Close disconnect switch.

2.27-96 8.5.13 Place HS-AYIOIEWP-1A in the STOP position.

$B B 2.27 .96$ 8.5.5 Verify that the green light for the recirculation pump is $O N$.

$3 B 2.27-96$ 8.5.6 Verify that the red light for the recirculation pump is $0 F F$.

B8 2.27.96 8.5.7 Place HS-AY101EWP-1A in the START position.

332.27 .968 .5 .8

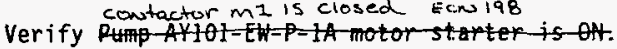

B 2.27 .968 .5 .9

Verify that the green light for the recirculation pump is OFF.

W030004.SP. 1232 
$83227.96-8.5 .10$

83 2.23.96 8.5.11

32.27968 .5 .12

3R. $2.27 .96 \quad 8.5 .13$

$2.27 .96 \quad 8.5 .14$

$28.27 .96 \quad 8.5 .15$

3 2.27-96 8.5.16
Verify that the red light for the recirculation pump is ON.

Place HS-AY101EWP-1Alin the STOP position.

Contactor $m 1$ is open ECN 198

Verify Pump AYHO1-EW-P-IA motor starter is OfF.

Verify that the green light for the recirculation pump is $O N$.

Verify that the red light for the recirculation pump is OFF.

Open disconnect switch.

Reconnect Motor Leads AY101EWP1A-T1, AY101EWP1A-T2, and AY101EWP1A-T3 to recirculation pump.

8.6. RECIRCULATION PUMP AYIO1-EW-P-1B (Reference Drawing H-2-131366, Sh 3)

2.87-96 8.6.1 Verify that the disconnect switch to Recirculation Pump AY101-EW-P-1B is OPEN or OFF.

2.27.96 8.6.2 Disconnect Motor Leads AY101EWP1B-T1, AY101EWPIB-T2, and AYl01EWP1B-T3 from Recirculation Pump AY101-EW-P-1B.

$332.27 .96-8.6,84$

$23.22 .96-8.6 \times 3$

$382.27 .96 \quad 8.6 .5$

$32.27 .96 \quad 8.6 .6$

38227.96 8.6.7

28.27 .96 8.6.8

38.27 .968 .6 .9

2.27.96 8.6.10

B8 2.27 .968 .6 .11

832.27 .968 .6 .12

$B 8.227 .968 .6 .13$

B8 2.27.96 8.6.14

$882.27 .95 \quad 8.6 .15$

38.27.96 8.6.16
Close disconnect switch.

ens 198

Place HS-AY101EWP-1BIin the STOP position.

Verify that the green light for the recirculation pump is ON.

Verify that the red light for the recirculation pump is OFF.

Place HS-AY101EWP-1BLin the START position.

constactor M1 is closed ECN 198

Verify PUAP-AY101-EH-P-1B-motor starter is-OH.

Verify that the green light for the recirculation pump is OFF.

Verify that the red light for the recirculation pump is $\mathrm{ON}$.

Place HS-AY101EWP-1BLin the STOP position.

contactor $m 1$ is opens EN 198

Verify Rump-AYOI-EW P-1B-motor stanter is Off.

Verify that the green light for the recirculation pump is ON.

Verify that the red light for the recirculation pump is off.

Open disconnect switch.

Reconnect Motor Leads AY101EWP1B-T1, AY101EWP1B-T2, and AY101EWP1B-T3 to recirculation pump.

8.7 FLUID COOLER SPRAY PUMP AY102-EW-SP-1 (Reference Drawing H-2-131366, Sh J JECN 198 282.27.26 8.7.1 Verify that the disconnect switch to Fluid Cooler UIC-AY102EWT-1 is OPEN or OFF. 
$332.22 .96 \quad 8.7 .2$

$2.27 .96 \quad 8.7 .3$

B3 2.27968 .7 .4

28.27 .968 .7 .5

2.27 .968 .7 .6

2.27.96 8.7.7

33.4 .968 .7 .8

$302.22 .96-8.7 .9$

$B 32.27 .96-8.7 .10$

$382.2796 \quad 8.7 .11$
Verify that Spray Pump Handswitch HS-AY102EWSP-1A is in the STOP-off position.

Verify that Fluid Cooler Fan Handswitch HS-AY102EWT-1A1 is in the offep position.

Verify that Pan Heater Handswitch HS-AY102EWT-1A2 is in the OFF position.

Verify that Damper Actuator Handswitch HS-AY102EWT-IA3 is in the AUTO position.

Verify that sump water make-up Isolation VaTve HV-AYIO2RW-I is CLOSED.

Verify that the spray pump sump is dry or water level is below the LSL-AY102EWT-1 level probes.

Delete $E x^{-1}-1$

Set timer of fan-on Delay-Relay-2MS, to 20 -seconds at control panel

HIG-AYIOZEWT 1 .

Disconnect Motor Leads AY102EWTI-1T1, AY102EWT1-1T2, and

AYI02EWT1-1T3 from spray pump.

Disconnect Power Leads AY102EWT1-3T1, AY102EWT1-3T2, and

AY102EWT1-3T3 from pan heater.

Install shorting switches at UIC-AY102EWT-1 between ILC level probe. terminals as follows:

38 2.27.96 8.7.11.1 Terminals "G" and "H, Switch " $H$ " in the ON or CLOSED position.

380 2.27.96 8.7.11.2 Terminals " $G$ " and " $L$," Switch " $L$ " in the ON or CLOSED position.

$B B$ 2.27.96 8.7.1.1.3 Terminals "G" and LLCO, Switch LLCO in the ON or CLOSED position.

NOTE: Shorting switches to remain in place until all tests associated with Fluid Cooler UIC-AY102EWT-1 have been completed.

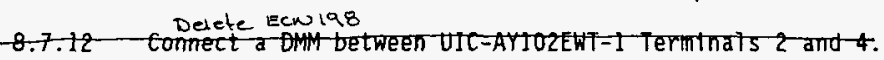

32.27 .96 8.7 1312 CLOSE disconnect switch (see Step 87.1 ). Eors 198

38 8.27-96 8.7.1413 Move Spray Pump Handswitch HS-AY102EWSP-1A to STARF position.

Contactor $1 \mathrm{~ms}$ Closes ECN 198

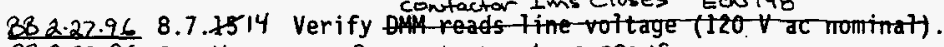

$382.27-96.7 .16$ verify contactor $1 \mathrm{~ms}$ opens

8.7 .16 Vexify spray pump motor starter is Ot.

882.27.96 8.7. HT15 Move Spray Pump Handswitch HS-AY102EWSP-1A to STOP position. eculas
The off
to stop position. Verify OMM reads o $V$ ae. Delde Contactor Ims cioses ECu 198

330.27 .968 .7 .1918 Verify spray pump motor starter is OFF. Ecu 198 the Local

38 2.27.96 8.7.2017 Move Spray Pump Handswitch HS-AY102EWSP-1A to START position. 
"H" ENO 198

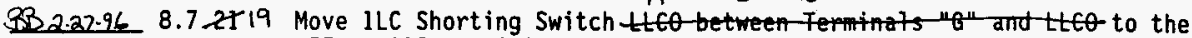
BB $2.27 .96 \quad 8.7 .20$ OFF OT OPEN position.

BB $2.27-96$ Verify contactor Ims remusus closed Ecrula8

$3.27 .96 \quad 8.7 .24$ 8.7 .25

Verify Pllt reads OY aE. move ILC Shorting switch "L" to the off position verify contactor $1 \mathrm{~ms}$ opens " $L "$ "The ecnsiag

Return ILC Shorting Switch $t t C \theta$ to 0 W

$$
\text { Een } 198
$$

Verify All4 roads fine-voltage. constactor Ims remuns open

move 1LC shorting switch "H" to the on position

$28.27 .96 \quad 8.72528$

$882.27 .96-8.7 .27$

332.27 .968 .7 .26

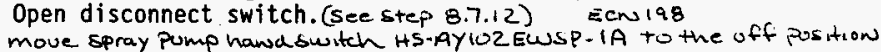

Disconnect OHA from UIC Terminals 2 and 4 . ECN 198

verify contuctor $1 \mathrm{~ms}$ closes

8.8

FLUID COOLER FAN HS-AYI02EWT-1AI (Reference Drawing H-2-131366, Sh ל)

BB $2.27-96 \quad 8.8 .1$

$28.27 .96 \quad 8.8 .2$

Q3.27.96 8.8 .3

3B $2.27 .96 \quad 8.8 .4$

$8 B 2.27-968.8 .5$

$882.27 .96 \quad 8.8 .6$

$3.4 .96 \quad 8.8 .7$

$382.22 .96 \quad 8.8 .8$

$3.22 .96 \quad 8.8 .9$

3.27 .968 .8 .10

$382.27 .96 \quad 8.8+1112$

$382.27 .96 \quad 8.8+2211$

$38.27 \cdot 968.8 .13$

$33.4 .96-8.8 .14$

$3 B .2 .27 .968 .8 .15$
Verify that the disconnect switch to Fluid Cooler UIC-AYIO2EWT-1 is OPEN or OFF.

Verify that Spray Pump Handswitch HS-AY102EWSP-1A is in the-SFOP off position.

Verify that Fluid Cooler Fan Handswitch HS-AY102EWT-1Al is in the off position.

Verify that Pan Heater Handswitch HS-AYI02EWT-1A2 is in the OFF position.

Verify that Damper Actuator Handswitch HS-AY102EWT-IA3 is in the AUTO position.

Verify that the sump water make-up Isolation Valve HV-AY102RW-1 is CLOSED.

Delete- ex*1

Set timer of fan on Detay Relay-2H5, to 20-seconds-at-Control

Pane? UIC-AYIOZENT-1.

Set inlet fan damper temperature controller range indicator at $60^{\circ} \mathrm{F}$ using the set point adjusting knob on top of the controller.

Set inlet fan damper temperature controller throttling range to minimum position using the adjusting screw next to the set point adjustment knob.

Remove inlet damper temperature element from thermowell and place temperature element in container of $75^{\circ} \mathrm{F}$ or greater, water. move spray pump hand switch HS.AYIOZEWSP-IA to the Local positions

fommect a blith between Terminals 2 and 11 . Ecw 198

CLOSE disconnect switch (see Step 8.2.1).

the lucal

Move Cooling Fan Handswitch HS-AY102EWT-1Al to STARF position. that contactor $2 \mathrm{~ms}$ closes eculas

Verify 0414 reads line-voltage $(120-\forall$ ae-nominal) after-approximately 20 -seconds. Detcte Ex 1

Verify cooling fan motor is rotating. 
Verify that inlet fan damper position indicator is in the OPEN

position.
Pace temperature eiement in a contanuer of cold water (Less than $60^{\circ} \mathrm{F}$ )

Eosition.
Pace temperature eiement ins a contancer of cold water (Less than $60^{\circ} \mathrm{F}$ )

$32.27 .96-8.8 .17$

$332.27 .96 \quad 8.8 .18$

Adjust intet damper temperature controller-ange indicator to-10-F.

B $2.27 .96 \quad 8.8 .19$

Verify that inlet fan damper position indicator moves to the CLOSED position.

B.2.27-96 8.8 .20

882.27 .968 .8 .21

Verify reats $198 \mathrm{~V}$ - Contuctor $2 \mathrm{~ms}$ opens

Verify cooling fan motor stops rotating. ECw 198

Pace tamperatuve element ins a contanuer of water $75^{\circ} \mathrm{F}$ or hotter

Adjust intet fan damper temperature controlter range-indicator to

-60 of.

$38.2 .27 .96 \quad 8.8 .22$

Verify that inlet fan damper position indicator is in the OPEN position.

$88.2 .27-96-8.8 .23$

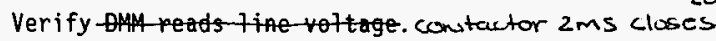
ECN 198

$38.27-96 \quad 8.8 .24$

Move Fan Control Handswitch HS-AY102EWT-1Al to the SFOP position.

$2.27 .96 \quad 8.8 .25$

Verify 144 roads O $V$ ag constactor zms opens 5 an 148

$B B 2.27 .96 \quad 8.8 .26$

OPEN disconnect switch. Ecw 198

$23.27 .96 \quad 8.8 .27$

move sanay pump handswitch to the off positions

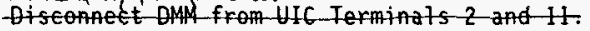

$28.27 .96 \quad 8.8 .28$

Remove inlet fan damper temperature element from container of water, dry element, and reinstall element in thermowell.

8.9

FLUIO COOLER PAN HEATERS (Reference Drawing H-2-131366, $5 \mathrm{~h}$ है)

30 2.27-96 8.9.1 Verify disconnect switch of fluid cooler is OPEN or OFF.

B3 2.27.96 8.9.2 Verify that Spray Pump Handswitch HS-AY102EWSP-1A is in the STOP off position.

2.27-96 8.9.3 Verify that Sump Water Make-up Isolation Valve HV-AYIO2RW-1 is CLOSED.

832.27 .96 8.9.4 Verify that the spray pump sump is dry or water level is below the LSL-AY102EWT-1 level probes.

$B B 3-y .96$ 8.9.5 Remove cover of pan heater thermostat housing and adjust thermostat to maxime temperature setting ( 150 degrees).

Delete ECn 198

8.9.6_ Delete Ecoint between Control Panel Terminats 2 and 20.

3827.96 8.9. 36 CLOSE disconnect switch.

32.27 .96 8.9. 7 Move the heater control handswitch to the ON position.

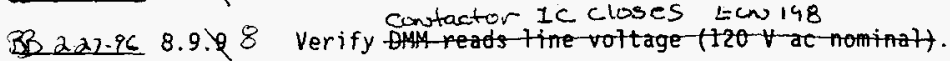

332.27 .96 8.9.1Q9 Move "ILC" Switch "LLCO" to the OFF or OPEN position.

W030004.SP. 1232

$-19-$

WHC-SD-W030-ATR-004

Rev 0

$01 / 16 / 95$ 


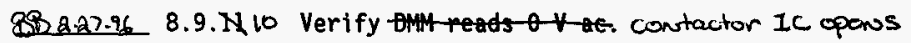

882.27 .96 8.9.12" Move "ILC" Switch "LLCO" to the ON or CLOSED position.

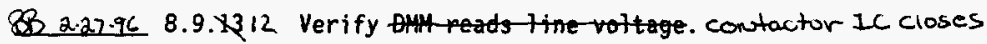

$283-4.96$ 8.9.1413 Adjust pan heater thermostat to minimum setting $\left(0^{\circ}{ }^{\circ} \mathrm{F}\right)$. ECN 198

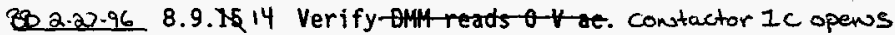

$833-4.96$ 8.9.1215 Adjust pan heater thermostat to maximum setting ( $150^{\circ} \mathrm{F}$ ).

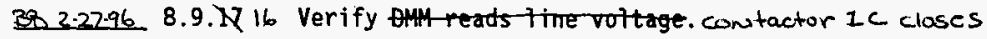

2.27.96 8.9.1\%17 Move heater control handswitch to the OFF position.

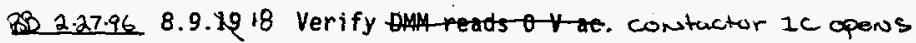

88 2.27.96 8.9.2Q19 OPEN disconnect switch.

Delete ECN 198

32.27 .96 8.9.8220 Adjust pan heater thermostat to $40^{\circ} \mathrm{F}$ setting and install thermostat housing cover.

8.10 FLUID COOLER MAKE-UP WATER SOLENOID VALVE EV-AYIO2EWT-1AI (Reference Drawing H-2-131366, Sh $\frac{\text { JJ) }}{4}$

2.27-96 8.10.1 Verify that the disconnect switch to Fluid Cooler UIC-AY102EWT-1 is OPEN or OFF.

2.27.96 8.10.2 Verify that Spray Pump Handswitch HS-AY102EWSP-1A is in the SFOP- Off position.

28.27 .96 8.10.3 Verify that Sump Water Make-up Isolation Valve HV-AY102RW-1 is CLOSED.

28 2.27.96 8.10.4 Verify that the spray pump sump is dry or the water level is below the LSL-AY102EWT-I level probes.

2.22 .96 8.10.5 CLOSE disconnect switch (see Step 8/7.1).

33 2.2796 8.10.6 Verify water make-up Solenoid Valve EV-AY102EWT-IAI is DE-ENERGIZED.

BS 2.27.96 8.10.7 Move ILC Shorting Switch "H" to the OFF or OPEN position.

$8 B 2.27 .96$ 8.10.8 Verify water make-up Solenoid Valve EV-AY102EWT-1Al is still DE-ENERGIZED.

PB 2.27.96 8.10.9 Move ILC Shorting Switch "L" to the OFF or OPEN position.

$B B \quad 2.27-96$ 8.10.10 Verify water make-up solenoid valve is ENERGIZED (Shorting Switch "L" must remain OFF or OPEN for at least 6 seconds before $1 L C$ energizes the valve).

3B 2.27-96 8.10.11 Move ILC Shorting Switch "L" to the ON or CLOSED position.

W030004.SP. 1232

$-20-$

WHC-SD-W030-ATR-004

Rev 0

$01 / 16 / 95$ 
32.27-96 8.10.12 Verify water make-up solenoid valve is still ENERGIZED.

2.27-96 8.10.13 Move ILC Shorting Switch "H" to the ON or CLOSED position.

B3_22-i6 8.10.14 Verify water make-up solenoid valve is DE-ENERGIZED (Shorting Switch "H" must remain ON or CLOSED for at least 6 seconds before ILC DE-ENERGIZES the valve).

BB2.22.96 8.10.15 OPEN disconnect switch (see Step 8, 18.1).

3827.96 8.10.16 Remove shorting switches at. UIC-AY102EWT-1 between ILC level probe.

33 2.22.96 8.10.17 Reconnect Motor Leads AY102EWT1-1T1, AY102EWT1-1T2, and AY102EWT1-1T3 to spray pump (see Step 8.X.9). Lon 798

Ba.22.96 8.10.18 Reconnect Power Leads AY102EWT1-3T1, AY102EWT1-3T2, and AY102EWT1-3T3 to pan heater (see Step $8, \frac{X}{7} .10$ ).

8.11 RECIRCULATION PUMP AY102-EW-P-1A (Reference Drawing H-2-131366, Sh $/ 3$ )

BB.2.2.96 8.11.1 Verify that the disconnect switch to Recirculation Pump AY102-EW-P-1A is OPEN or OFF.

$B B$ 2.27-96 8.11.2 Disconnect Motor Leads AY102EWP1A-T1, AY102EWP1A-T2, and AY102EWP1A-T3 from Recirculation Pump AY102-EW-P-1A.

230.27 .96 8.11.\$4 Close disconnect switch.

BBQ277-96 8.11, $\$ 3$ Place HS-AYI02EWP-1A in the STOP position.

$B$ 2.27.96 8.11.5 Verify that the green light for the recirculation pump is $0 N$.

832.27 .96 8.11.6 Verify that the red light for the recirculation pump is $0 F F$.

38 2.27-26 8.11.7 Place HS-AYJO2EWP-1A in the START position.

BB 2.27.96 8.11.8 Verify PumP-AY102-EW=P-1A motor starter-is $0 N$.

B 2.27 .96 8.11.9 Verify that the green light for the recirculation pump is OFF.

2.27-96 8.11.10 Verify that the red light for the recirculation pump is $0 N$.

Q 2.27-96 8.11.11 Place HS-AY102EWP-1A in the STOP position.

BB 2.27-96 8.11.12 Verify Pump-AY102-EW-P-IA-motor stafter-is-OfF.

83 2.27-96 8.11.13 Verify that the green light for the recirculation pump is $0 N$.

BB 2.27.96 8.11.14 Verify that the red light for the recirculation pump is $0 F F$.

2.27.96 8.11.15 0pen disconnect switch.

2.27.96 8.11.16 Reconnect Motor Leads AY102EWP1A-T1, AY102EWP1A-T2, and AY102EWP1A-T3 to recirculation pump. 
8.12 RECIRCULATION PUMP AY102-EW-P-IB (Reference Drawing H-2-131366, Sh 4 ). $\begin{array}{ll}3 B \text { 2.27.96 8.12.1 } & \begin{array}{l}\text { Verify that the disconnect switch to Recirculation Pump AY102-EW-P-1B } \\ \text { is OPEN or OFF. }\end{array}\end{array}$

3.27.96 8.12.2 Disconnect Motor Leads AY102EWP1B-T1, AY102EWP1B-T2, and AY102EWP1B-T3 from Recirculation Pump AY102-EW-P-1B.

8227.96 8.12.34 Close disconnect switch.

382.27 .26 8.12.43 Place HS-AY102EWP-181in the STOP position.

2.22.96 8.12.5 Verify that the green light for the recirculation pump is oN.

$332.22-96$ 8.12.6 Verify that the red light for the recirculation pump is OFF.

B2.27.96 8.12.7 Place HS-AY102EWP-1B1in the START position.

BR 2.27.96 8.12.8 Verify Puntactor MI is Closed EN-EN-18-motor-starter is ON.

322.27.96 8.12.9 Verify that the green light for the recirculation pump is off.

B 2.27-96 8.12.10 Verify that the red light for the recirculation pump is 0 .

QB8 2.22.96 8.12.11 Place HS-AY102EWP-1BLin the STOP position.

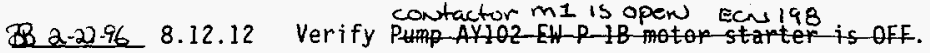

B2.27.96 8.12.13 Verify that the green light for the recirculation pump is $O N$.

23. 25.12 .14 Verify that the red light for the recirculation pump is OFF.

38.27.96 8.12.15 Open disconnect switch.

BB Q-27-96 8.12.16 Reconnect Motor Leads AY102EWP1B-T1, AY102EWP1B-T2, and AY102EWP1B-T3 to recirculation pump.

END OF SECTION 8

W030004.SP. 1232 
This test will demonstrate the integrity of the instruments and equipment associated with the tank recirculating condensation cooling systems located at the AZ evaporator pad. (Reference Drawings $\mathrm{H}-2-131069$, Sh $1, \mathrm{H}-2-131070$, Sh 1 , and $\mathrm{H}-2-131357$, Sh 1)

9.1 FLUID COOLER SPRAY PUMP AZ101-EW-SP-1 (Reference Drawing H-2-131366, Sh 5)

B $227-96$ 9.1.1 Verify that the disconnect switch to Fluid Cooler UIC-AZ101EWT-1 is OPEN or OFF.

B 2.27-96 9.1.2 Verify that Spray Pump Handswitch HS-AZ101EWSP-1A is in the SFOP- off position.

3.27-96 9.1.3 Verify that Fluid Cooler Fan Handswitch HS-AZ101EWT-1A1 is in the offop position.

Q 2-27-96 9.1.4 Verify that Pan Heater Handswitch HS-AZ101EWT-1A2 is in the OFF position.

2.27-96 9.1.5 Verify that Damper Actuator Handswitch HS-AZ101EWT-1A3 is in the AUTO position.

32.27 .96 9.1.6 Verify that sump water make-up Isolation Valve HV-AZl01RW-1 is CLOSEO.

38 2.27.96 9.1.7 Verify that the spray pump sump is dry or water level is below the LSL-AZ101EWT-1 level probes.

30 3-4.96 9.1.8 Set timer of fan on Delay Relay-245, to-20 seconds at control panel UIC-AZ10IEWT-1.Delete EX $* 1$

3B2.27.96 9.1.9 Disconnect Motor Leads AZ101EWT1-1T1, AZ101EWT1-1T2, and AZ101EWTI-1T3 from spray pump.

3B 2:27-96 9.1.10 Disconnect Power Leads AZ101EWT1-3T1, AZ101EWT1-3T2, and AZlolEWT1-3T3 from pan heater.

38.2.27-26 9.1.11 Install shorting switches at UIC-AZ101EWT-1 between ILC level probe terminals as follows:

38 2.27.96 9.1.11.1 Terminals "G" and "H," Switch " $H$ " in the ON or CLOSED position.

R2.27.96 9.1.11.2 Terminals "G" and "L," Switch "L" in the ON or CLOSED position.

BB2-27-96 9.1.11.3 Terminals "G" and LLCO, Switch LLCO in the ON or CLOSED pOsition.

NOTE: Shorting switches to remain in place until ail tests associated with Fluid Cooler UIC-AZ101EWT-I have been completed.

Delete ECW 198

-9.1.12 Connect a QHA4 between UIC-AZTOIEHT-1 Terminats 2 and-4.

B 2.27-96 9.1.1312 CLOSE disconnect switch (see Step 9.1.1).

B2.27-96 9.1.1312 CLOSE disconnect switch (see step 9.1.1). the local

3B 2.27.96 9.1.1413 Move Spray Pump Handswitch HS-AZ101EWSP-1A to -SFARf position.

W030004.SP. 1232 
B2a296 The off

Be 2.27.96 9.1.1715 Move Spray Pump Handswitch HS-AZ101EWSP-1A to STOP position.

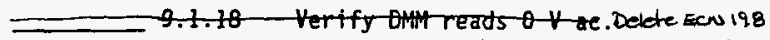

BB 2-27.96 9.1.1918 Verify contactor Ims closes Een 198

The local

$33227-96$ 9.1.2017 Move Spray Pump Handswitch HS-AZ101EWSP-1A to-STARF position.

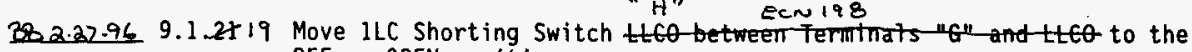

382.27 .969 .1 .20 OFF or OPEN position.

ses.2.26 9.1.20 verify contactor 1 ims remains closed ten 198

$38.22-26$ 9.1.22 21 Verify DHt reads O Y aE move $1 L C$ shorting switch" $L "$ to the off position

$38.27 .96-9.1 .22$

882.27 .919 .1 .23

Verify contactor 1 ms opens The ECNI98

Return ILC Shorting Switch "LCO to $L$ "Th or CLOSED position.

$38.27 .96 \quad 9.1 .24$

$\frac{8 B 2.27 .96}{8.96} 9.1 .25$

Verify reads tinte vottage. contactor Ims remains open move ILC shorting switch " $H$ " to the ons positions

$B B 2.27869 .1 .2528$

BB 2.22 .969 .1 .27

Open disconnect switch. (SELE STEP 9.1 .12 ) ECW 198

$3 B 2.27-969.1 .26$

move spray pump handswitch HS-AZ10IEWSP-IA to the off position

Diseonnet OMH-from-UIE ferminals 2 and 4 .

verify contactor 1 ms closes Eens 198

9.2 FLUID COOLER FAN UIC-AZ101EWT-1 (Reference Drawing H-2-131366, Sh 5)

$382.27 .96-9.2 .1$

Verify that the disconnect switch to Fluid Cooler UIC-AZ101EWT-1 is. OPEN or OFF.

$862796-9.2 .2$

Verify that Spray Pump Handswitch HS-AZ101EWSP-1A is in the STOP off position.

32 2.27-96 9.2.3 Verify that Fluid Cooler Fan Handswitch HS-AZ101EWT-1Al is in the offer position.

2.27.96 9.2.4 Verify that Pan Heater Handswitch HS-AZ101EWT-1A2 is in the OFF position.

2.22-96 9.2.5 Verify that Damper Actuator Handswitch HS-AZ101EWT-1A3 is in the AUTO position.

$2.27 .96 \quad 9.2 .6$

Verify that the sump water make-up Isolation Valve HV-AZ101RW-1 is CLOSED.

$38.3 .4 .96 \quad 9.2 .7$

Set-timer of fan-on-Delay Relay-2445, to-20-seconds at control

Pane?-UIG-AZ101EWT-1. Derete Ex *1

$38 \quad 2.27 .96-9.2 .8$

Set inlet fan damper temperature controller range indicator at $60^{\circ} \mathrm{F}$ using the set point adjusting knob on top of the controtler.

2.27.26 9.2.9 Set inlet fan damper temperature controller throttling range to minimum position using the adjusting screw next to the set point adjustment knob. 
Remove inlet damper temperature element from thermowell and place temperature element in container of $75^{\circ} \mathrm{F}$ or greater, water. move spray pump handswitch is-Az lol sw SP. I A to the local position

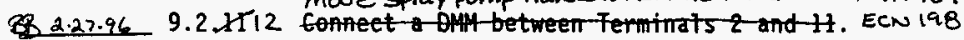

$38.27-46,9.2 .1211$

B 2.27 .9

Delete

Exciption 4

9.2 .13

9.2 .14

9.2 .15

9.2 .16

9.2.17

9.2 .18

9.2 .19

9.2 .20

9.2 .21

9.2 .22

9.2 .23

9.2 .24

9.2 .25

9.2 .26

9.2 .27

9.2 .28

CLOSE disconnect switch (see Step 9.2.1).

Move Cooling Fan Handswitch HS-AZ10IEWT-1Al to START position. rhat constactor $2 \mathrm{~ms}$ closes aensiag. Verify 444 reads-line-voltage (120 $V$ ac nominal) after approximately 20 seconds.

Verify cooling fan motor is rotating.

Verify that inlet fan damper position indicator is in the OPEN

position. ECn 198 .

Adjust-intet-damper temperature controlier range indtcator to 10 - $F$.

Verify that inlet fan damper position indicator moves to the CLOSED position.

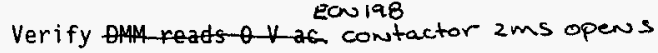

Verify cooling fan motor stops rotating.

ECN 198

Place temperature element in a contawer of $75^{\circ} \mathrm{F}$ or hotter water

Adjust intet-fan-damper temperature comtroller range-indicator to

bo af.

Verify that inlet fan damper position indicator is in the OPEN position.

Verify HA4-reads time voltage. Contactor $2 \mathrm{~ms}$ closes

Move Fan Control Handswitch HS-AZ101EWT-1Al to the SFOP position. ECon 198

Verify ts $\theta-v$ - contactor $2 \mathrm{~ms}$ opews

OPEN disconnect switch.

Move spray Pump havdswitch to the off position

Oisconnect PHA from UIE Ferminats 2 - Ecus 198

Remove inlet fan damper temperature element from container of water, dry element, and reinstall element in thermowell.

9.3 FLUID COOLER PAN HEATER UIC-AZ101EWT-1 (Reference Drawing H-2-131366, Sh 5)

BB 2.27.96 9.3.1 Verify disconnect switch of fluid cooler is OPEN, or OFF.

38 2.22.96 9.3.2 Verify that Spray Pump Handswitch HS-AZ101EWSP-1A is in the SfOP position.

33 2.27-96 9.3.3 Verify that Sump Water Make-up Isolation Valve HV-AZlolRW-1 is CLOSED.

W030004.SP. 1232

WHC-SD-W030-ATR-004

Rev 0

$01 / 16 / 95$ 
83223.96 9.3.4 Verify that the spray pump sump is ory or water level is below the [SL-AZ10IEWT-1 level probes.

9.3.5 Remove cover of pan heater thermostat housing and adjust thermostat to maximum temperature setting (150 degrees).

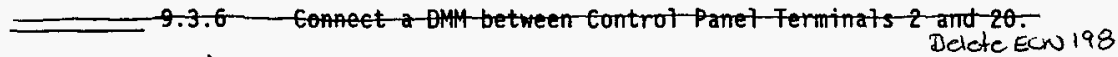

9.3.2. 26 CLOSE disconnect switch.

2.22 .96 9.3.8 7 Move the heater control handswitch to the ON position.

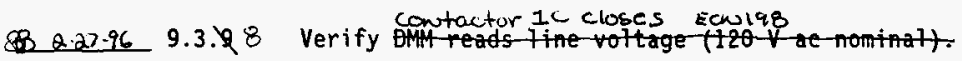

2.27.9L 9.3. NQ9 Move "ILC" Switch "LLCO" to the OFF or OPEN position.

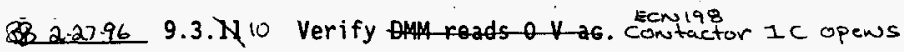

2.27-96 9.3. . 2 " Move "1LC" Switch "LLCO" to the ON or CLOSED position.

BB 2.27-96 9.3. 312 Verify 1444 reads line voltage. constuctor 16 closes

383.4 .96 9.3. 13 Adjust pan heater thermostat to maxmum sexting $\left(0_{50}^{\circ}{ }^{\circ}\right.$ ).

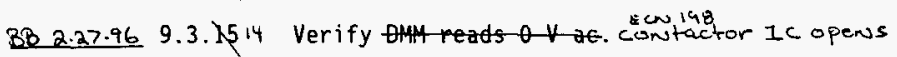

383.4 .969 .3 .1615 Adjust pan heater thermostat to-maximum setting (150 $0_{0}^{\circ} \mathrm{F}$ ).

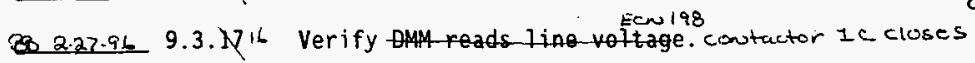

$3 B 2.27-96$ 9.3.1817 Move heater control handswitch to the OFF position.

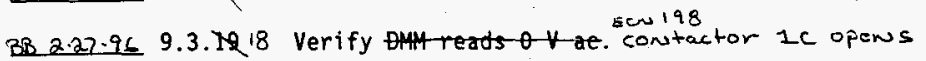

B3227.96 9.3.2Q19 OPEN disconnect switch.

BB 2.27.96 9.3.2220 Adjust pan heater thermostat to $40^{\circ} \mathrm{F}$ setting and install thermostat
housing cover.

9.4 FLUID COOLER MAKE-UP WATER SOLENOID VALVE EV-AYIOIEWT-IAI (Reference Drawing $\mathrm{H}-2-131366$, Sh 5)

BB 2.27-96 9.4.1 Verify that the disconnect switch to Fluid Cooler UIC-AZ101EWT-1 is OPEN or OFF.

2.22-96 9.4.2 Verify that Spray Pump Handswitch HS-AZ101EWSP-1A is in the -SFOPposition.

23.27.96 9.4.3 Verify that Sump Water Make-up Isolation Valve HV-AZ101RW-1 is CLOSED.

$\triangle B$ 2.27. 96 9.4.4 Verify that the spray pump sump is dry or the water level is below the LSL-AZ101EWT-1 level probes.

W030004.SP. 1232 
3.27-96 9.4.5 CLOSE disconnect switch (see Step 9.4.1).

B 2.27-96 9.4.6 Verify water make-up Solenoid Valve EV-AZIOIEWT-IAl is DE-ENERGIZED.

Q.27.96 9.4.7 Move ILC Shorting Switch "H" to the OFF or OPEN position.

2.27.96 9.4.8 Verify water make-up Solenoid Valve EV-AZ101EWT-1Al is still DE-ENERGIZED.

2.27-96 9.4.9 Move ILC Shorting Switch "L" to the OFF or OPEN position.

28.27.96 9.4.10 Verify water make-up solenoid valve is ENERGIZED (Shorting Switch " $L$ " must remain OFF or OPEN for at least 6 seconds before ILC energizes the valve).

B.2.27.96 9.4.11 Move ILC Shorting Switch "L" to the ON or CLOSED position.

2.27-96 9.4.12 Verify water make-up solenoid valve is still ENERGIZED.

Q 2.27-96 9.4.13 Move ILC Shorting Switch " $h "$ to the ON or CLOSED position.

BBa.27.96 9.4.14 Verify water make-up solenoid valve is DE-ENERGIZED (Shorting

Switch "H" must remain ON or CLOSED for at least 6 seconds before 1 LC DE-ENERGIZES the valve).

38.2.27-96 9.4.15 OPEN disconnect switch (see Step 9.4.1).

28.27.96 9.4.16 Remove shorting switches at UIC-AZ101EWT-1 between ILC level probe.

2.22.86 9.4.17 Reconnect Motor Leads AZ101EWT1-1T1, AZ101EWT1-1T2, and AZ101EWT1-1T3 to spray pump (see Step 9.1.9).

2.22-96 9.4.18 Reconnect Power Leads AZ101EWT1-3T1, AZ101EWT1-3T2, and AZ101EWT1-3T3 to pan heater (see Step 9.1.10).

9.5 RECIRCULATION PUMP AZ101-EW-P-1A (Reference Drawing H-2-131366, Sh 5)

B 2.27-96 9.5.1 Verify that the disconnect switch to Recirculation Pump AZ101-EW-P-1A is OPEN or OFF.

B 2.27.96 9.5.2 Disconnect Motor Leads AZ101EWP1A-T1, AZ101EWP1A-T2, and AZ101EWPIA-T3 from Recirculation Pump AZ101-EW-P-1A.

R_a.22.26 9.5. $3 / 4$ Close disconnect switch.

BR2.27.96 9.5.43 Place HS-AZ101EWP-1ALin the STOP position.

32 Verify that the green light for the recirculation pump is 0 . 9.5.5

9.5.6 Verify that the red light for the recirculation pump is OFF.

BB 2.27.96 9.5.7 PIace HS-AZ101EWP-1ALin the START position.

BB2-27.96 9.5.8 Verify Ptmp AZ101-EW-P-1A motor starter-is- $0 A$.

$B 3$ 2.27-96 9.5.9 Verify that the green light for the recirculation pump is 0 FF. 
IB 2.27.96 9.5.10 Verify that the red light for the recirculation pump is 0 .

2.27-96 9.5.11 Place HS-AZ101EWP-1A in the STOP position.

28.27 .96 9.5.12 Verify Pump-AZ101-EH-P-1A-motor-startep-is-OfF:

(3.27.96 9.5.13 Verify that the green light for the recirculation pump is $O N$.

2.27.96 9.5.14 Verify that the red light for the recirculation pump is OFF.

Q 2.27 .96 9.5.15 Open disconnect switch.

2.27.96 9.5.16 Reconnect Motor Leads AZ101EWP1A-T1, AZ101EWP1A-T2, and AZ10IEWP1A-T3 to recirculation pump.

9.6 RECIRCULATION PUMP AZ101-EW-P-1B (Reference Drawing H-2-131366, Sh 5)

227.96 9.6.1 Verify that the disconnect switch to Recirculation Pump AZ101-EW-P-1B is OPEN or OFF.

2.27.96 9.6.2 Disconnect Motor Leads AZ101EWP1B-T1, AZ101EWP1B-T2, and AZ101EWP1B-T3 from Recirculation Pump AZ101-EW-P-1B.

$28.27 .96 \quad 9.6 .34$ Close disconnect switch.

2.27.96 9.6.43 Place HS-AZ101EWP-1B in the STOP position.

2.27.96 9.6.5 Verify that the green light for the recirculation pump is $0 N$.

28.27.96 9.6.6 Verify that the red light for the recirculation pump is OFF.

BB2.27.96 9.6.7 Place HS-AZ101EWP-1B in the START position.

BB2-22-96 9.6.8 Verify Pump AZ101-EH-P-1B-motor stater is $0 \mathrm{Ht}$

2.27-96 9.6.9 Verify that the green light for the recirculation pump is OFF.

B8 2.27 .96 9.6.10 Verify that the red light for the recirculation pump is $O N$.

Q.22-96 9.6.11 Place HS-AZ101EWP-1B in the STOP position.

38 2.22-96 9.6.12 Verify Rump AZ101-EH-P-18-motor-starter is OFF,

20 2.27.96 9.6.13 Verify that the green light for the recirculation pump is 0 .

3.22.96 9.6.14 Verify that the red light for the recirculation pump is OFF.

27.96 9.6.15 disconnect switch.

BB 2.27-96 9.6.16 Reconnect Motor Leads AZ101EWP1B-T1, AZ101EWP1B-T2, and AZ101EWP1B-T3 to recirculation pump.

9.7 FLUID COOLER SPRAY PUMP AZ102-EW-SP-1 (Reference Drawing H-2-131366, Sh 6)

B82.27-96 9.7.1 Verify that the disconnect switch to Fluid Cooler UIC-AZ102EWT-1 is OPEN or OFF. 
B 2.27-96 9.7.2 Verify that Spray Pump Handswitch HS-AZ102EWSP-1A is in the SfOP position.

B2.27.96 9.7.3 Verify that Fluid Cooler Fan Handswitch HS-AZ102EWT-IAl is in the offep position.

B2.27.96 9.7.4 Verify that Pan Heater Handswitch HS-AZ102EWT-1A2 is in the OFF position.

B 2.27.96 9.7.5 Verify that Damper Actuator Handswitch HS-AZ102EWT-1A3 is in the AUTO position.

Q 2.27.96 9.7.6 Verify that sump water make-up Isolation Valve HV-AZ102RW-1 is CLOSED.

B.2.27.96 9.7.7 Verify that the spray pump sump is dry or water level is below the LSL-AZ102EWT-1 level probes.

83 3-4.96 9.7.8 Set-timer of fan on Dolay Relay $2 M 5$, to 20 seconds at control panel UIC-AZ102EWT-I.Delete EX 1 .

BB 2227.96 9.7.9 Disconnect Motor Leads AZ102EWT1-1T1, AZ102EWT1-1T2, and AZ102EWT1-1T3 from spray pump.

BS2.27.96 9.7.10 Disconnect Power Leads AZ102EWT1-3T1, AZ102EWT1-3T2, and AZ102EWT1-3T3 from pan heater.

3B 2.27.96 9.7.11 Install shorting switches at UIC-AZ102EWT-1 between ILC level probe terminals as follows:

29.2796 9.7.11.1 Terminals "G" and "H," Switch "H" in the ON or CLOSED position.

2.27.96 9.7.11.2 Terminals "G" and "L," Switch "L" in the ON or CLOSED position.

B 2.27.96 9.7.11.3 Terminals "G" and LLCO, Switch LLCO in the ON or CLOSED position.

NOTE: Shorting switches to remain in place until all tests associated with Fluid Cooler UIC-AZ102EWT-1 have been completed.

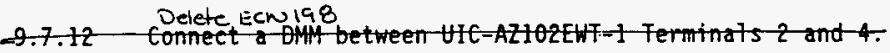

3.20.96 9.7.25 12 CLOSE disconnect switch (see Step 9.7.1).

B 2.22.96 9.7.2413 Move Spray Pump Handswitch HS-AZ102EWSP-1A to START position.

B 2.22.96 9.7. 1514 Verify DMM reads line voltage (120 V ac nominal).

B 2.27 .96 9.7.16 Verify spray pump motor starter is ON.

2327-96 9.7.1715 Move Spray Pump Handswitch HS-AZ102EWSP-1A to STOP position.

Delete tow 198

9.7 .18 Verify OHM reads 0 - Ver.

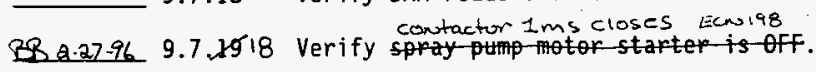

IB 2.27.96 9.7,2017 Move Spray Pump Handswitch HS-AZ102EWSP-1A to STARF position.

W030004.SP. 1232 


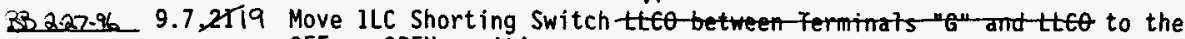
$92.27-96,9.7 .20$ OFF or OPEN position.

Verify constactor Ims remains closed Eensia8

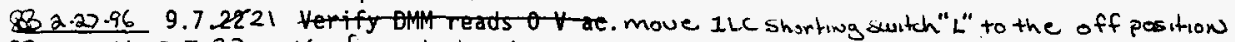

$632.22 .96 \quad 9.7 .22$

$\frac{2.27 .96}{2.27 .7 .23}$

Verify contactor Ims opens the

Return ILC Shorting Switch $H C \theta$ tot

$832.27 .96 \quad 9.7 .24$

$182.27-969.7 .25$

Verify OMAt reads time voltage. Contactor $1 \mathrm{~ms}$ remans open

$\frac{2.27-96}{25.7 .2528}$

$2.27-96 \quad 9.7 .27$

move ILC shorting switch " $H$ " to the on position

$2.27-96 \quad 9.7 .26$

Open disconnect switch. (See step 9.7.12) Ecro 198

move spray pump handswitch HS-AZ102 EW SP-IA to the off positions

Bisconnect OMM from-UIE Ferminals-2 and-4, Ecm 198

9.8

Verify contactor Ims closes

2023-96 9.8.1 Verify that the disconnect switch to Fluid Cooler UIC-AZ102EWT-1 is OPEN or OFF.

B 2.27-i6 9.8.2 Verify that Spray Pump Handswitch HS-AZ102EWSP-1A is in the STOP- off position.

20.27-96 9.8.3 Verify that Fluid Cooler Fan Handswitch HS-AZ102EWT-1A1 is in the STOP position.

2.27 .96 9.8.4 Verify that Pan Heater Handswitch HS-AZ102EWT-1A2 is in the OFF position.

B8 2.27-96 9.8.5 Verify that Damper Actuator Handswitch HS-AZ102EWT-1A3 is in the AUTO position.

2.27.96 9.8.6 Verify that the sump water make-up Isolation Valve HV-AZ102RW-l is CLOSED.

$33.4 .96 \quad 9.8 .7$

Set timer of fam on Delay-Retay-2HS, to 20 seconds at Contro-

PaneT-UIC-AZ102EWT-T. Delete EX $* 1$

33 2.27-96 9.8.8 Set inlet fan damper temperature controller range indicator at $60^{\circ} \mathrm{F}$ using the set point adjusting knob on top of the controller.

32.27 .96 9.8.9 Set inlet fan damper temperature controller throttling range to minimum position using the adjusting screw next to the set point adjustment knob.

$3 B$ 2.27.96 9.8.10 Remove inlet damper temperature element from thermowe 11 and place temperature element in container of $75^{\circ} \mathrm{F}$ or greater, water.

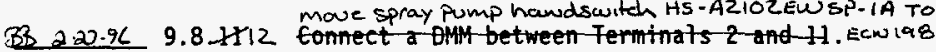

3 2.27.96 9.8.tZ) CLOSE disconnect switch (see Step 9.8.1).

B 2.27-96 9.8.13 Move Cooling Fan Handswitch HS-AZ102EWT-1Al to-STARF position. that constactor $2 \mathrm{~ms}$ closes ECNISB

$333.4-96$ 9.8.14 Verify BMA reads-line-voltage (120 Vac nominat) after-approximately 20 - seconds. Delete Ex -1

Deete

W030004.SP. 1232

$-30-$

WHC-SD-W030-ATR-004

Rev 0

$01 / 16 / 95$ 


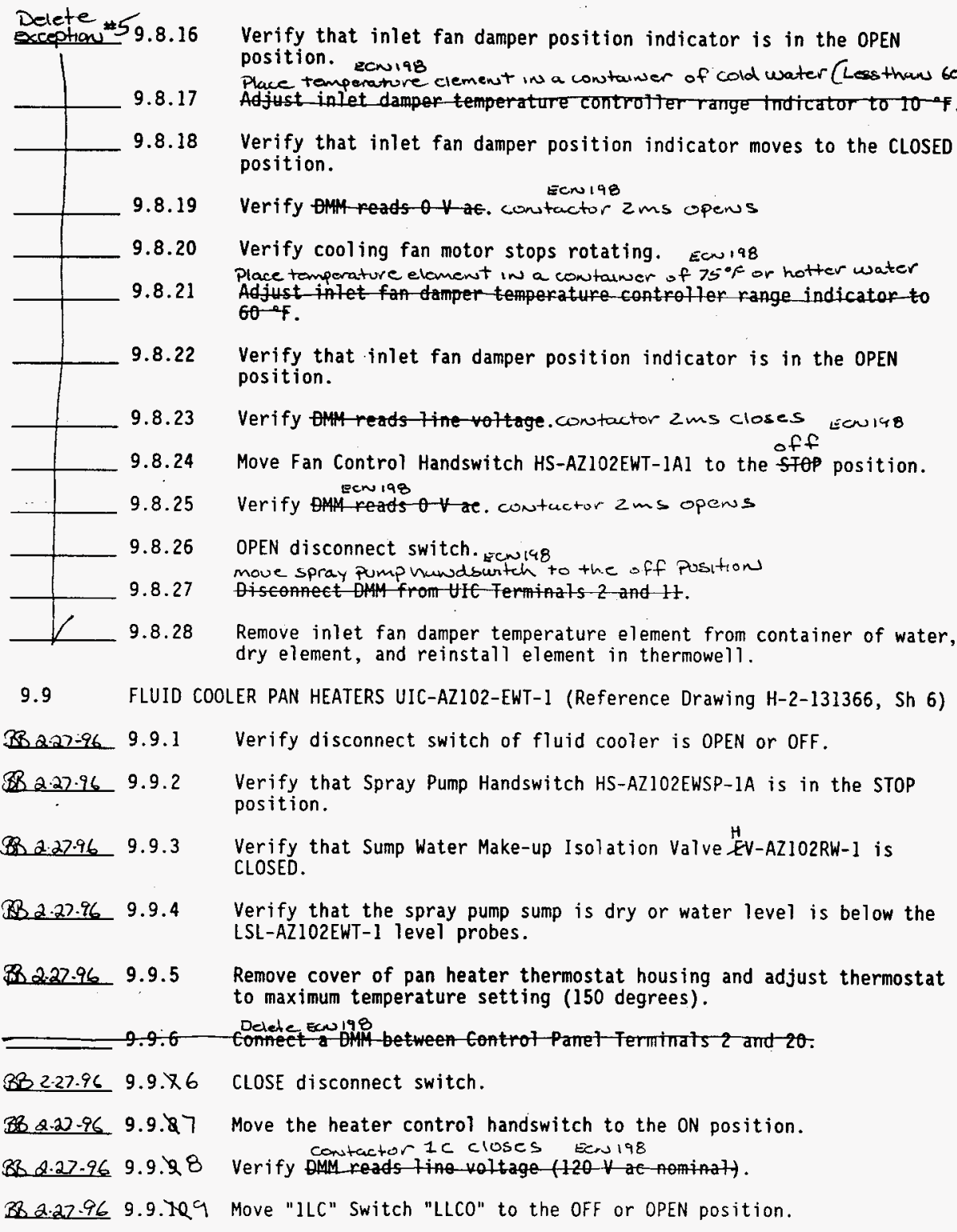


2.2296 9.9.1110 Verify - Contactor IC opows

3.27-96 9.9.2KII Move "ILC" Switch "LLCO" to the ON or CLOSED position.

2.27.96 9.9.2312 Verify OMM-reads tine voltage. Constactor $1 \mathrm{C}$ closes

38.3 .4 .969 .9 .1413 Adjust pan heater thermostat to maximum Eximum setting $\left.{ }^{*}{ }^{\circ}{ }^{\circ} \mathrm{F}\right)$.

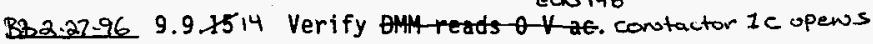

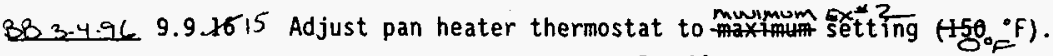

BB 2.22-96 9.9 -1716 Verify OM reads Time-roltage. Contactor 16 closes

382.27 .96 9.9. 3817 Move heater control handswitch to the OFF position.

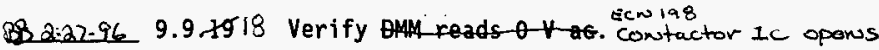

38 8.27.96 9.9.2014 OPEN disconnect switch.

Delete ECN 198

Discontect-OMH:-

227.969 .9 .2220 Adjust pan heater thermostat to $40^{\circ} \mathrm{F}$ setting and install thermostat housing cover.

9.10 FLUID COOLER MAKE-UP WATER SOLENOID VALVE EV-AZ102EWT-1Al (Reference Drawing $\mathrm{H}-2-131366$, Sh 6)

B 2.2796 9.10.1 Verify that the disconnect switch to Fluid Cooler UIC-AZ102EWT-I is OPEN or OFF.

2-27.96 9.10.2 Verify that Spray Pump Handswitch HS-AZ102EWSP-1A is in the STOP off position.

932 2.27-96 9.10.3 Verify that Sump Water Make-up Isolation Valve HV-AZlO2RW-1 is CLOSED.

33 2.27-96 9.10.4 Verify that the spray pump sump is dry or the water level is below the LSL-AZ102EWT-1 level probes.

2.27.96 9.10.5 CLOSE disconnect switch (see Step 9.10.1).

2-27.96 9.10.6 Verify water make-up Solenoid Valve EV-AZ102EWT-IAI is DE-ENERGIZED.

2.27.96 9.10.7 Move ILC Shorting Switch "H" to the OFF or OPEN position.

$B$ 2.27-96 9.10.8 Verify water make-up Solenoid Valve EV-AZ102EWT-1AI is still DE-ENERGIZED.

2.27.96 9.10.9 Move ILC Shorting Switch " $L$ " to the OFF or OPEN position.

BB 2.27.96 9.10.10 Verify water make-up solenoid valve is ENERGIZED (Shorting Switch "L" must remain OFF or OPEN for at least 6 seconds before $1 \mathrm{LC}$ energizes the valve).

23.27.96 9.10.11 Move ILC Shorting Switch "L" to the ON or CLOSED position.

W030004.SP. 1232 
B3 2.27-96 9.10.12 Verify water make-up solenoid valve is still ENERGIZED.

28-27.46 9.10.13 Move ILC Shorting Switch "H" to the ON or CLOSED position.

2.27-96 9.10.14 Verify water make-up solenoid valve is DE-ENERGIZED (Shorting

Switch "H" must remain ON or CLOSED for at least 6 seconds before ILC DE-ENERGIZES the valve).

2.27.96 9.10.15 OPEN disconnect switch (see Step 9.10.1).

28.27.96 9.10.16 Remove shorting switches at UIC-AZ102EWT-1 between ILC level probe.

BB 2.27-96 9.10.17 Reconnect Motor Leads AZ102EWT1-1T1, AZ102EWT1-1T2, and AZ102EWT1-1T3 to spray pump (see Step 9.7.9).

38-2.27.96 9.10.18 Reconnect Power Leads AZ102EWT1-3T1, AZ102EWT1-3T2, and AZ102EWT1-3T3 to pan heater (see Step 9.7.10).

9.11 RECIRCULATION PUMP AZ102-EW-P-1A (Reference Drawing H-2-131366, Sh 6)

$B B$ 2.27.96 9.11.1 Verify that the disconnect switch to Recirculation Pump AZ102-EW-P-1A is OPEN or OFF.

BB 2.22-96 9.11.2 Disconnect Motor Leads AZ102EWP1A-T1, AZ102EWP1A-T2, and

AZ102EWP1A-T3 from Recirculation Pump AZ102-EW-P-1A.

BB 2.27-96 $9.11 \not 34$ Close disconnect switch.

38 2.27.9C 9.11 $\$ 3$ Place HS-AZ102EWP-1A in the STOP position.

$B B$ 2.27-96 9.11.5 Verify that the green light for the recirculation pump is $O N$.

32.27 .96 -9.11.6 Verify that the red light for the recirculation pump is 0 FF.

2.2796 9.11.7 Place HS-AZ102EWP-1A in the START position.

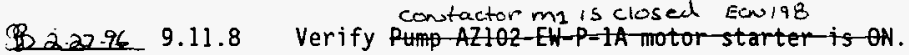

2 2.27.96 9.11.9 Verify that the green light for the recirculation pump is off.

B2.27-96 9.11.10 Verify that the red light for the recirculation pump is $0 N$.

B. 2.27.96 9.11.11 Place HS-AZ102EWP-1A in the STOP position.

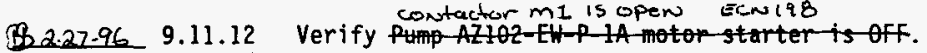

136 227.96 9.11.13 Verify that the green light for the recirculation pump is $0 N$.

2.27.96 9.11.14 Verify that the red light for the recirculation pump is OFF.

28.27.76 9.11.15 Open disconnect switch.

38 2.27-96 9.11.16 Reconnect Motor Leads AZ102EWPIA-T1, AZ102EWP1A-T2, and AZ102EWP1A-T3 to recirculation. pump.

W030004.SP. 1232 


\subsection{RECIRCULATION PUMP AZ1Q2-EW-P-1B (Reference Drawing H-2-131366, Sh 6)}

B2.27-96 9.12.1 Verify that the disconnect switch to Recirculation Pump AZ102-EW-P-1B is OPEN or OFF.

Q.27-96 9.12.2 Disconnect Motor Leads AZ102EWPIB-T1, AZ102EWP1B-T2, and AZ102EWP1B-T3 from Recirculation Pump AZ102-EW-P-1B.

Q $2.22-96 \quad 9.12,844$ Close disconnect switch.

Q-27.96 $9.12,43$ Place HS-AZI02EWP-1BLin the STOP position.

B.2.27-96 9.12.5 Verify that the green light for the recirculation pump is oN.

Q 2.2) 96 9.12.6 Verify that the red light for the recirculation pump is OFF.

B2.27.96 9.12.7 Place HS-AZ102EWP-1BIin the START position.

RB 0 Contactor $m 1$ is closech EN 198

Q 2.27-96 9.12.8 Verify Pump-AZ102-EW=P=1B motor starter is ON:

3 $8.27-96$ 9.12.9 Verify that the green light for the recirculation pump is ofF.

2.27-96 9.12.10 Verify that the red light for the recirculation pump is 0 .

B.27-96 9.12.11 Place HS-AZ102EWP-1BLin the STOP position.

32.27.96 9.12 .12 Verify Punp-AZ10Z-EH=P-10 motor starter-is OFF.

BB2-27-96 9.12.13 Verify that the green light for the recirculation pump is oN.

2-27-96 9.12.14 Verify that the red light for the recirculation pump is OFF.

2.27-96 9.12.15 Open disconnect switch.

863 2.27-96 9.12.16 Reconnect Motor Leads AZ102EWP1B-T1, AZ102EWP1B-T2, and AZ102EWP1B-T3 to recirculation pump.

END OF SECTION 9 


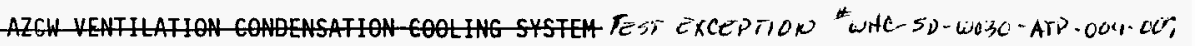

This test will demenstrate the integrity of the instruments and equipment associated with the AZCW ventilation condenstion cooling system. (Reforonce Prawing $112+131071$, Sh-1.)

10.1 CHILLEQ WAFER RECIRCULATION-PUMP-AZ-CW-P-1A fReference Orawing-H-2-131366, Sh-7)

NOIE: -All steps-are pexformed at the chillep pad untes otherwise noted. (Reference-Orawing H-2-131357, Sh-1)

10.1.1 Verify that the disconnect switeh-to Recireutation Pump-AZ-CW-P-1A-is OPEN ON OFF.

10.1-2 Disconnect Motor Leads AZCWP1A-T1, AZCWPIA-T2, and AZCWP1A-T3 from Recirculation Pump-AZ-CW-P-1A.

10.1.3 Close disconnect switeh.-

10.1.4 Place HS AZCWP IA in the STOP pOsition.

40.1.5. Verify that the green light for the recirculation pump is ON.

10.1.6 Verify that the red light for the focirculation pum is off.

10.1.7_Pface HS AZCWR IA in the START position.

10.1.8 Verify Pump-AZ-GW-P-1A mator starter-is-ON.

10.1.9 Verify that-the green- light for the

10.1.10 Verify that-the-red light for the reeireutation pump is oft.

10.1.11-Place HS-AZEWP-1A in the STOP position.

10:1.12 Verify Pump-AZ-EW-P-1A-mor-starter-is OfF.

10.1.13- Verify that the green-light for the recifoutation pum is on.

10.1.14 Verify that the red-Tight for the recirculation pump is OFF.

10.1.15-Open disconnect switeh.

10.1.16-Reconnet Motor Leads AZCWPIA-T1, AZCWPIA- T2, and AZCWPIA-T3 to recifeutation pump.

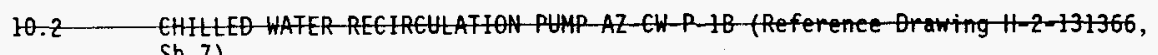
$\sin 7$ )

NOTE: All-steps-are performed at the chiller pad unless othewise-notedtReference Drawing $\mathrm{H}=2-131357$, Sh 1 )

10.2.1 Verify that the disconnet switeh to Recireutation-Pump AZ-CW-P-1B is OPEN Or OFF: 


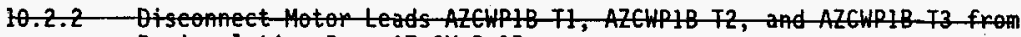
Aecireulation Pum AZ-EH-P-1B.

10.2.3-Close disconnect switeh.

10.2.4 PTace-HS-AZCWP-18-in the-STOP position.

10.2.5 Verify that the green-light for the recirculation pump-is $-\mathrm{N}$.

10.2.6 Verify that the red light for the recircutation pump is OFF.

10.2 .7 PIae HS-AZCWR 18 in the START-position.

10.2 .8 Verify Pum AZ CW P - 1B motor-starter is OA.

10.2 .9 - Verify that the green light fon-the ree i

10.2.10, Verify that the red light for the recireulation pump is ON.

10.2.11 Place HS-AZCWP is in the STOR-position.

10.2 .12 Verify Pump-AZ CWP 18 motor starter is $05 F$.

10.2.13 Verify that the green-light for the recireutation pump-is-out.

10.2 .14 Verify that the red light for the recipethation pump is OFF:

10.2.15 - Open disconnect switch.

to.2.16 Reconnect Hotor teads-AZCWPIB-T1, AZCWPIB-TZ, aA AZCWPIB-T3 to recirculation-pumpo-

END OF SECTION 10 


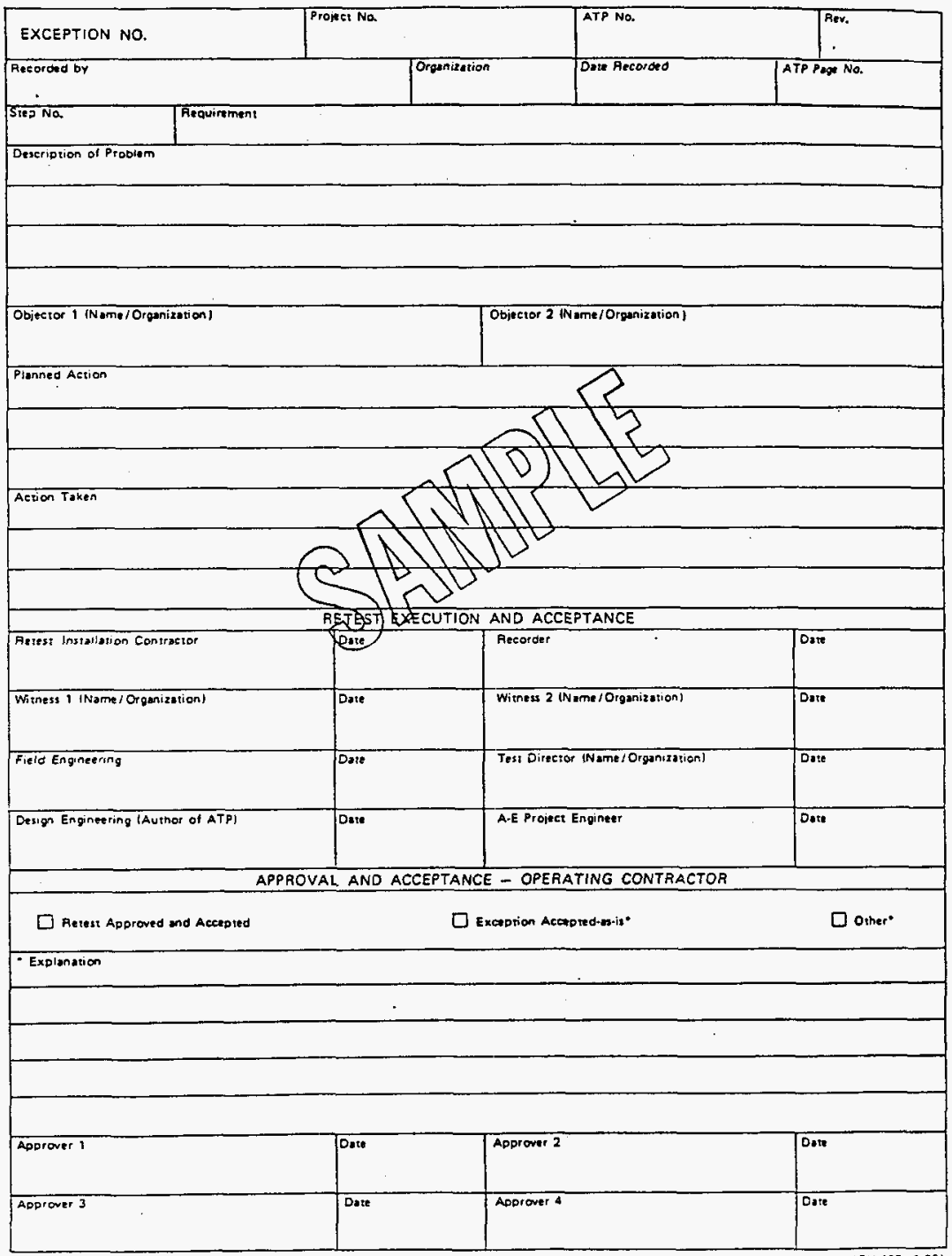




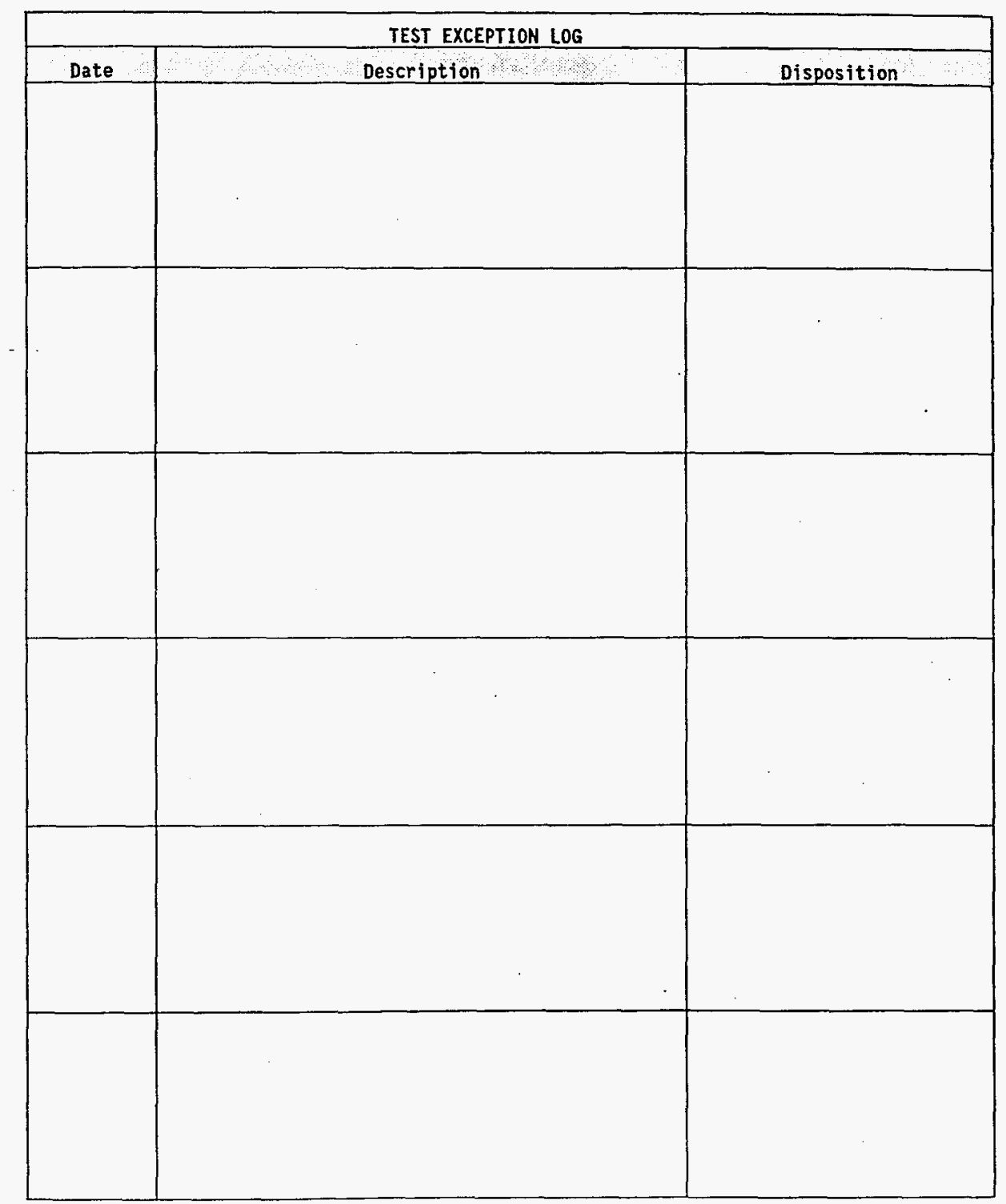

W030004.SP. 1232 


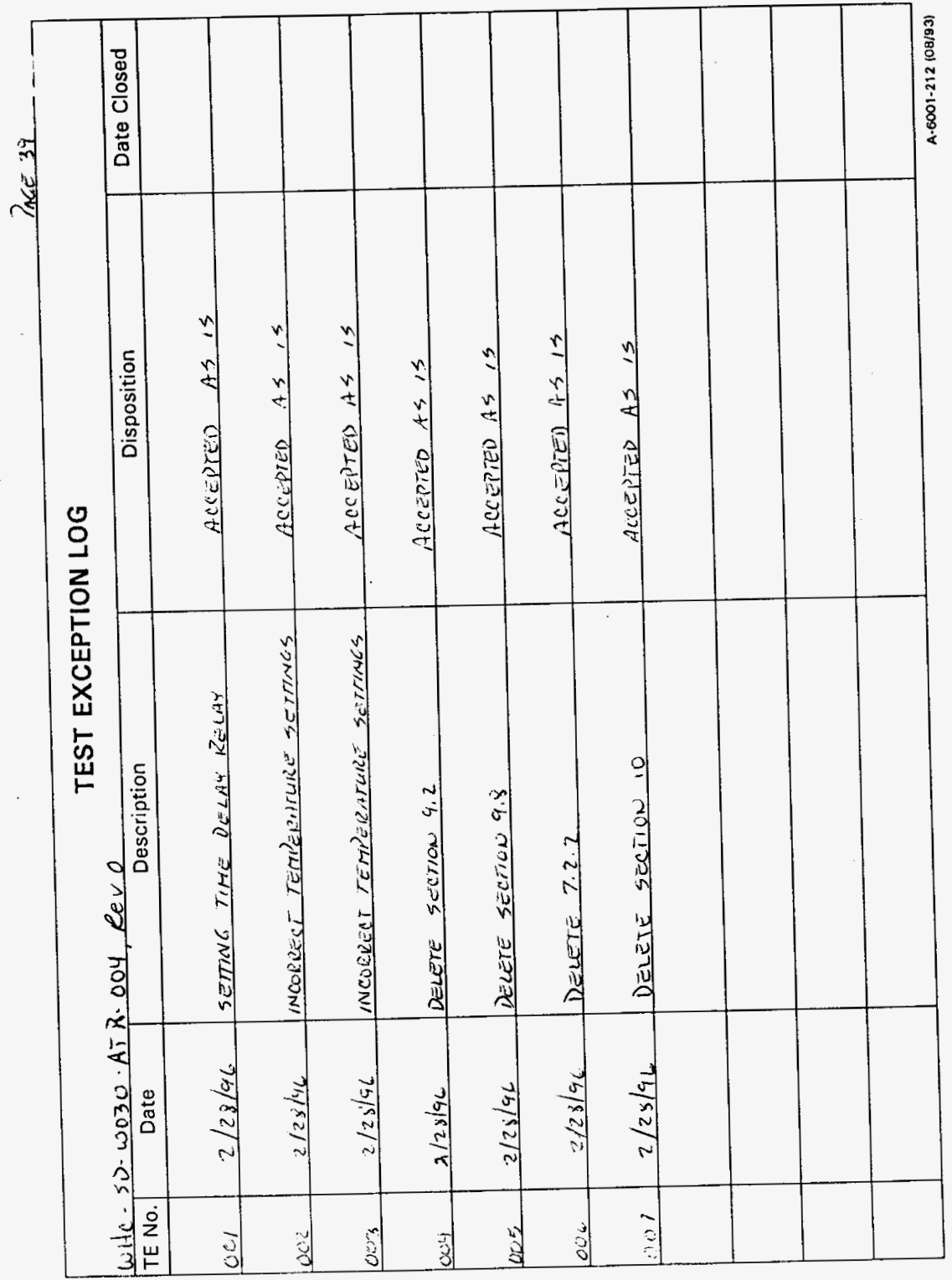


EXCEPTION NO.

WHC-5D-WOZO-ATP-004-COI

Recorded by

Gerals itayes

Stip No.

SEE ATTHChMENT

Descrip:ion of Frobiem

Requiremen:
ATP NO. $\frac{\omega H C-5 D-\omega 030-A T R-004}{\text { Date Recorded }} 0$ $2 / 2 8 \longdiv { 8 6 }$ SEE ATHACHeWT

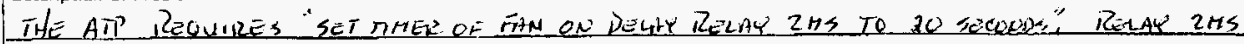
is Not A rime DéaY RelaS.

Osjecter 1 (Nima!Orgnizztion)

Obietier 2 (Name/Oranizgtion)

Fisnned Action

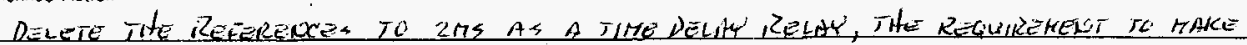

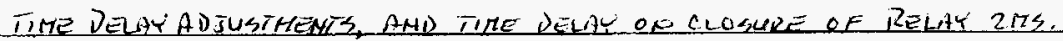

Action Taks

Tite. RefERENGes WERE DeLETEN AND TESTING COMTINUED

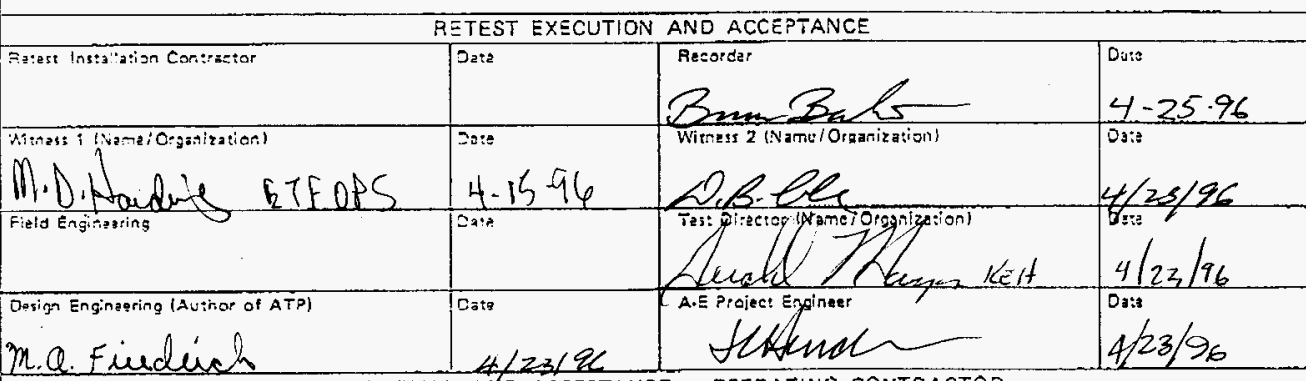

APPROVAL ANO ACCE?TANCE - OFERATING CONTRACTOR

Raier: Appreved and Accapied

Q Exception Accepisz-as:is"

Othet.

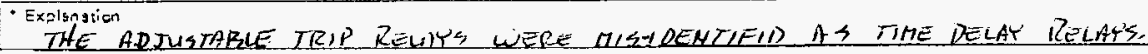

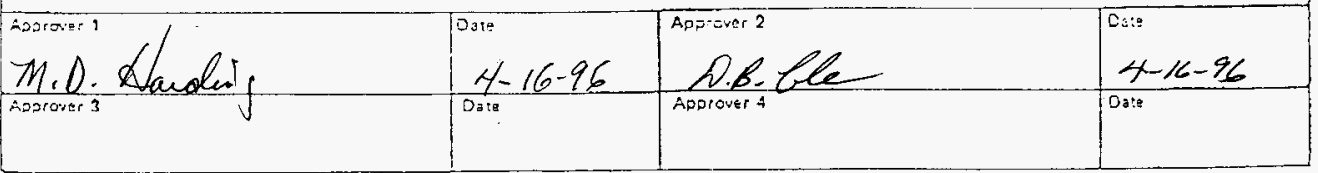


ATTACHMENT TO TEST EXCEPTION WHC-SD-M030-004-001, Rev 0

STEP NUMBER

8.1.8

8.2.7

8.2.14

8.7.8

8.8.7

8.8.14

9.1 .8

9.2 .7

9.2 .14

9.7 .8

9.8.7

9.8.14

PAGE NUMBER

11

12

13

17

18

18

23

24

25

29

30

30 


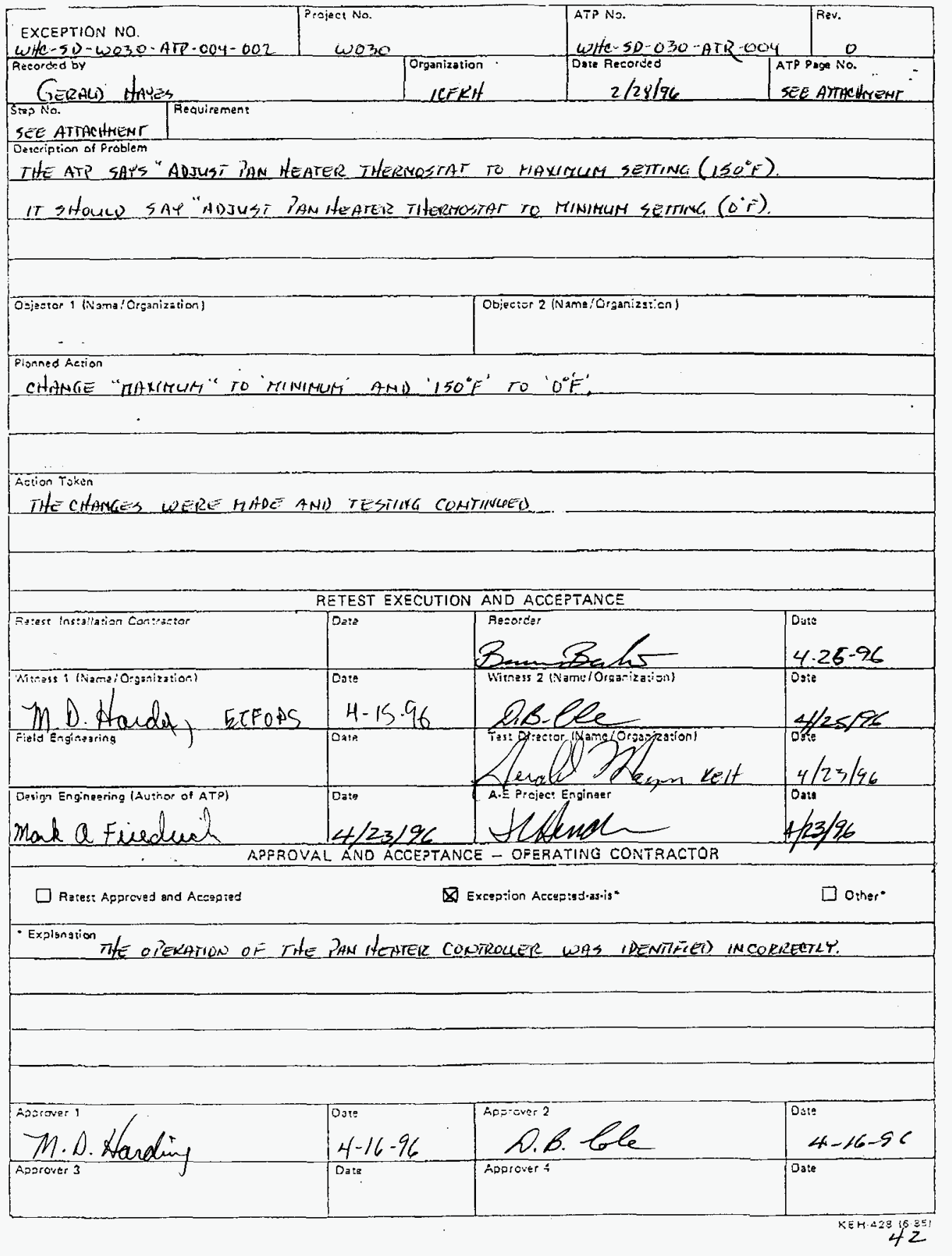


AT R Rer 0

ATTACHMENT TO TEST EXCEPTION HHC-SD-HO30-004-002

STEP NUMBER

8.3 .5

8.3.15

8.9.5

8.9 .15

9.3.5

9.3 .15

9.9 .5

9.9.15
PAGE NUMBER

14

14

19

20

26

26

31

32 
$\nrightarrow \rightarrow$

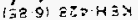

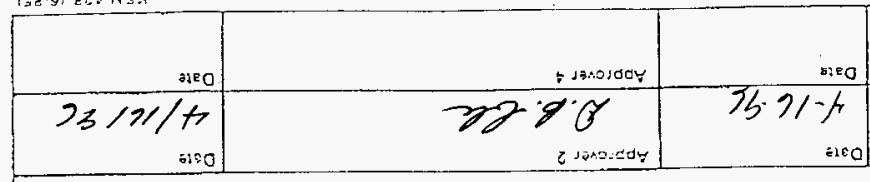

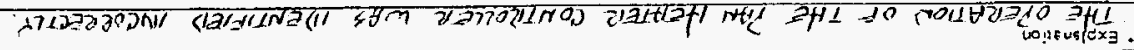

.2400

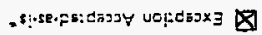

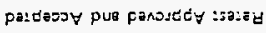

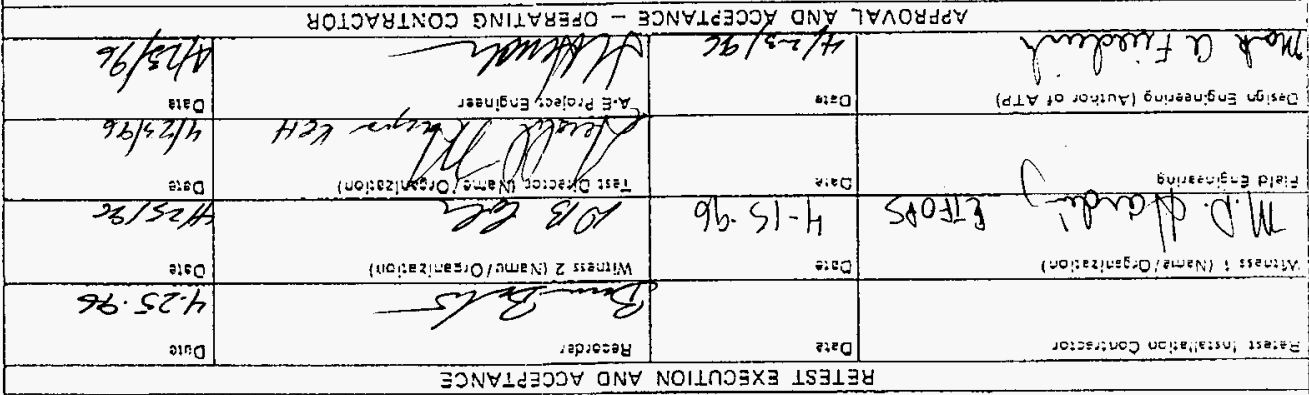

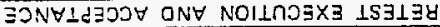

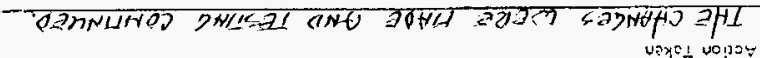

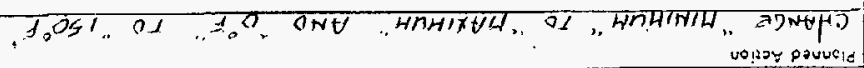

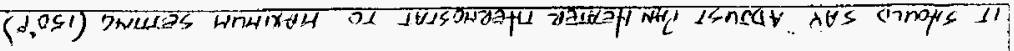

?

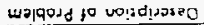

\begin{tabular}{|c|c|c|c|c|}
\hline \multicolumn{5}{|c|}{ 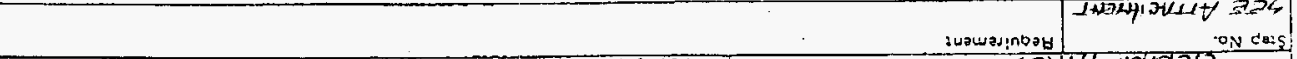 } \\
\hline 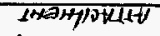 & $96 / 82 / 2$ & म1त्र 121 & sest & प्र जसत्वरक \\
\hline "ON DEe & 978 & . Lo!jeziues.o| & & Ne piososay \\
\hline \begin{tabular}{l|l}
0 \\
$0 \leq 4$
\end{tabular} & 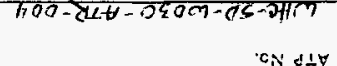 & Oदd & Em-hoo-d & 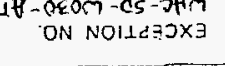 \\
\hline
\end{tabular}


ATR

ATTACHMENT TO TEST EXCEPTION MHC-SD-W030-004-003. ReVO

STEP NUMBER

8.3.13

8.9.13

9.3.13

9.9 .13
PAGE NUMBER

14

20

26

32 


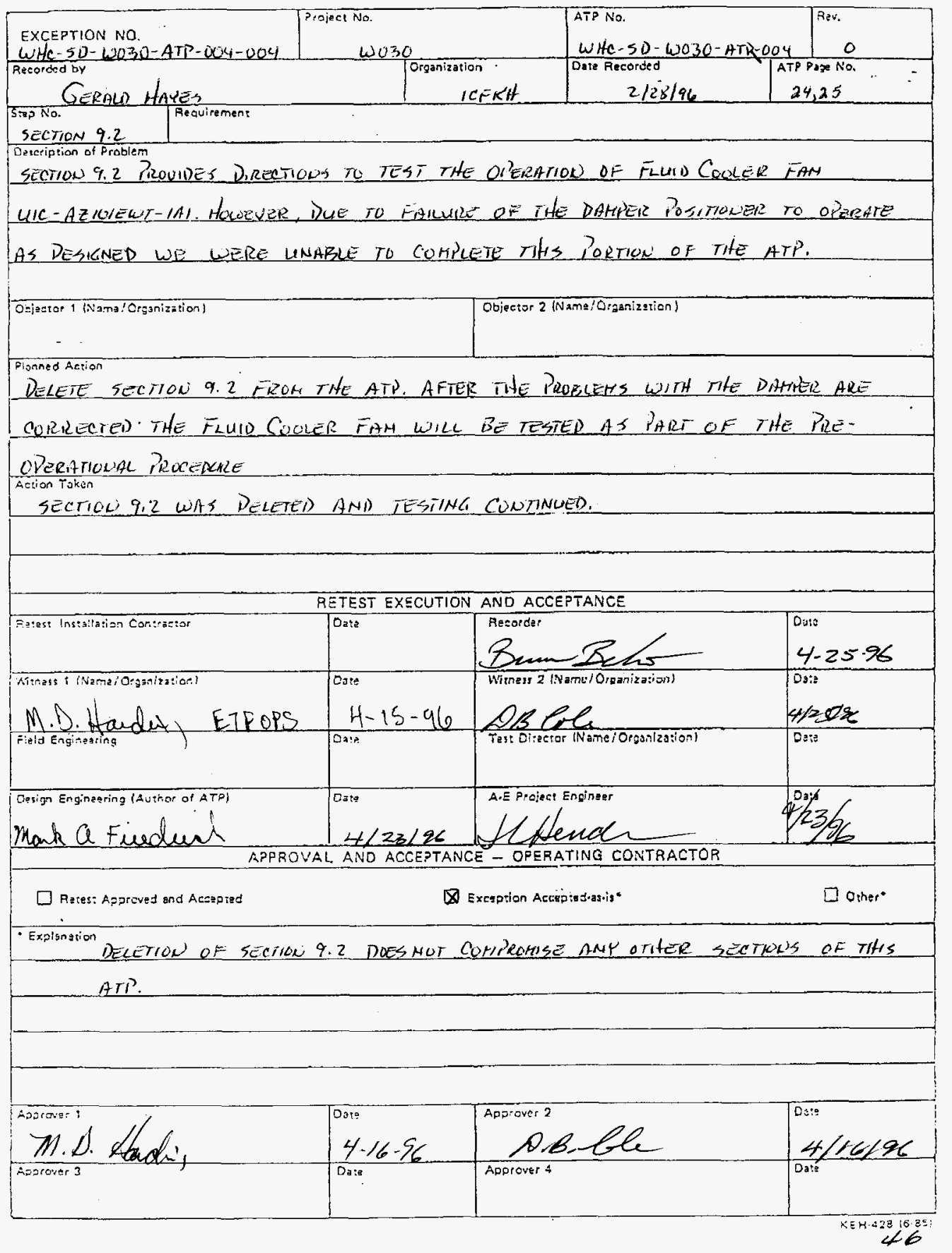




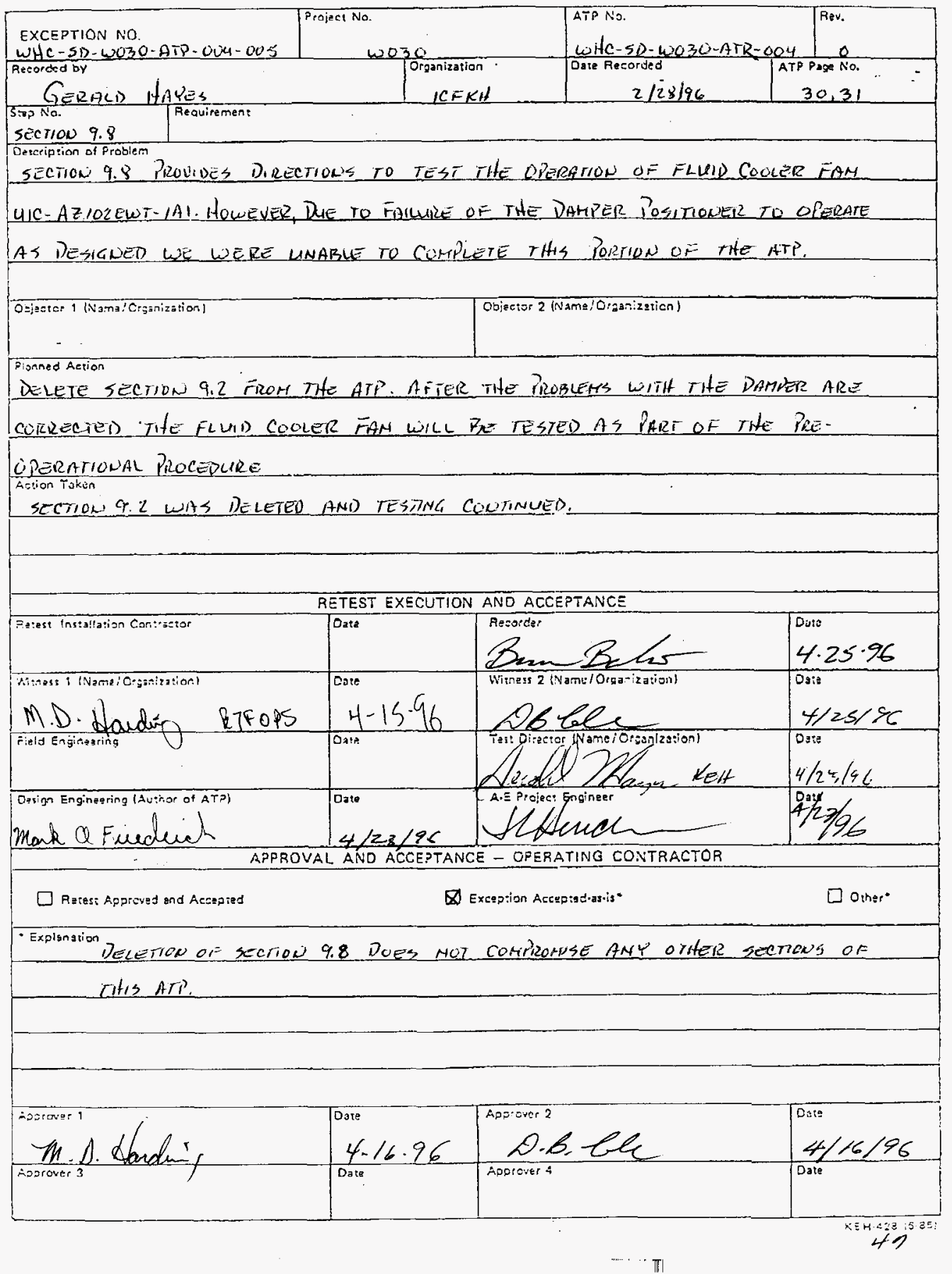




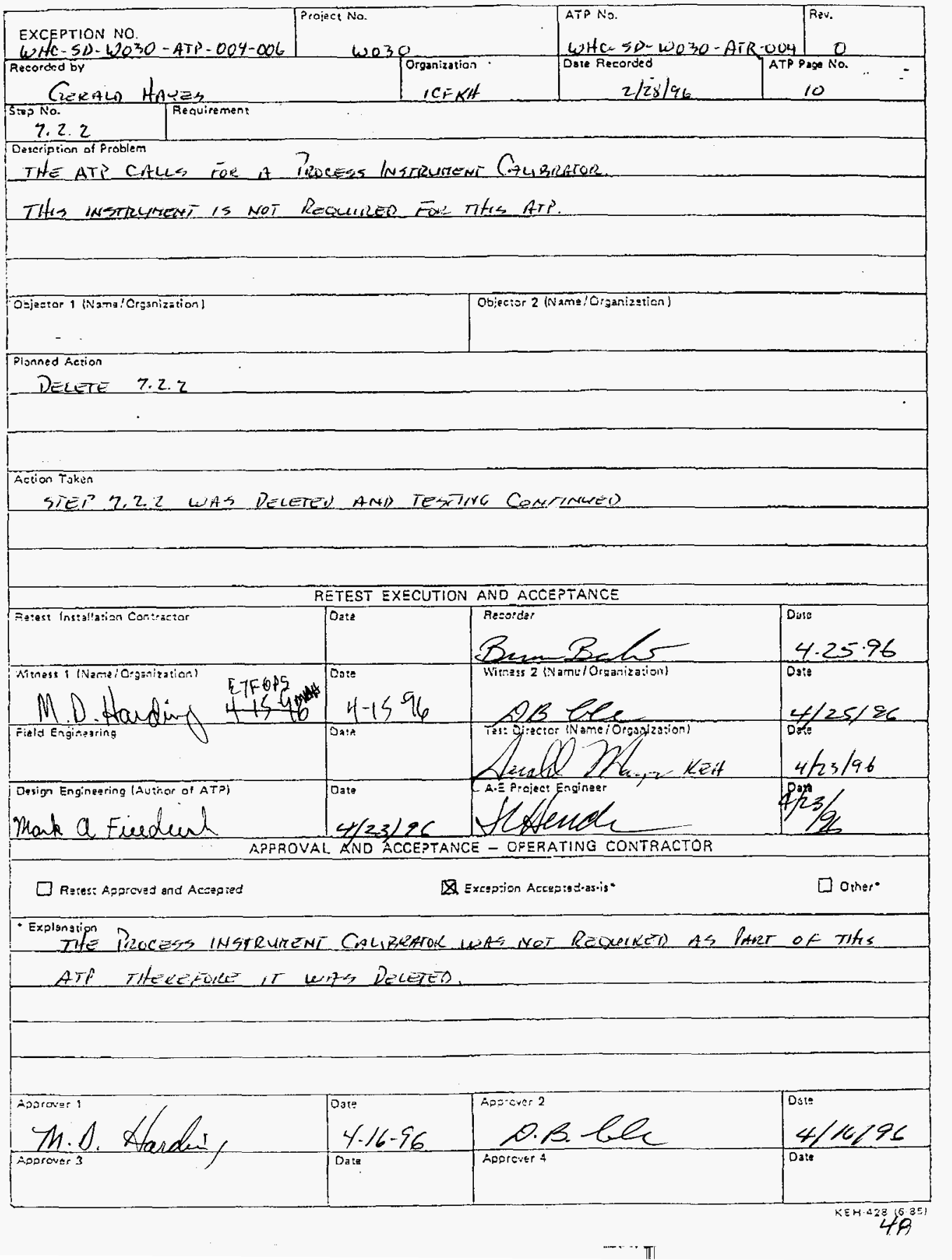




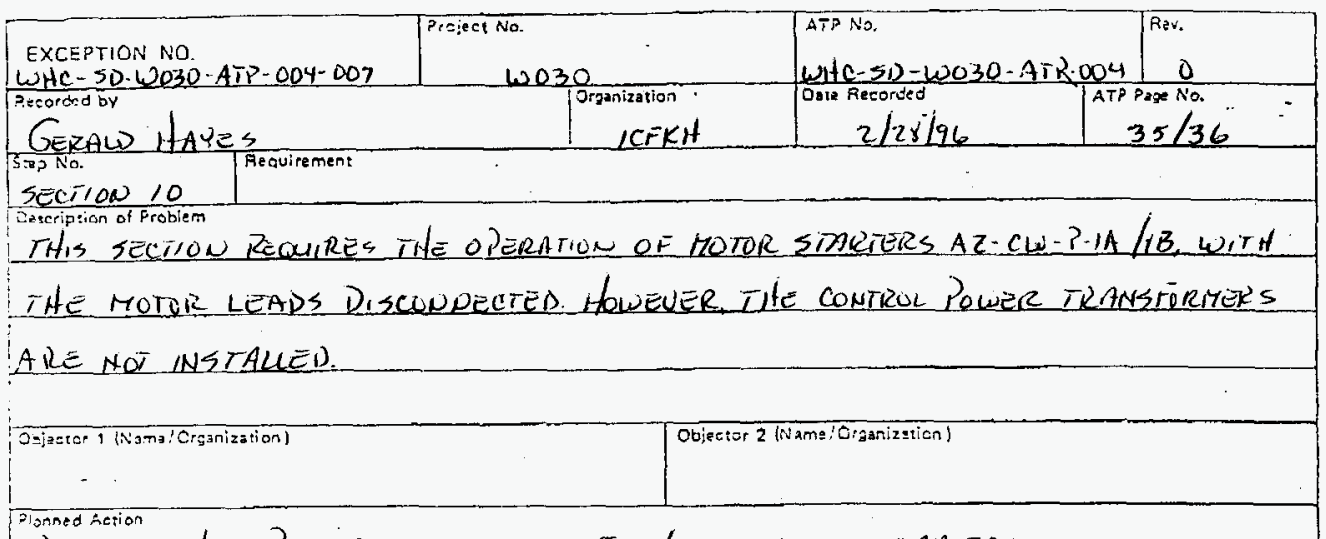

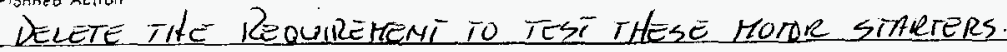

TAESE MOTOR STMRTERS WIL BE TESTEO AS PAR OF THE ?RE-OP TESTING.

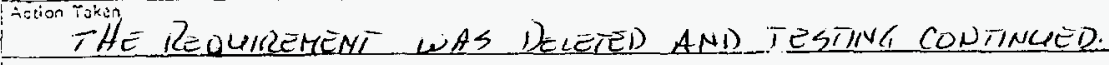

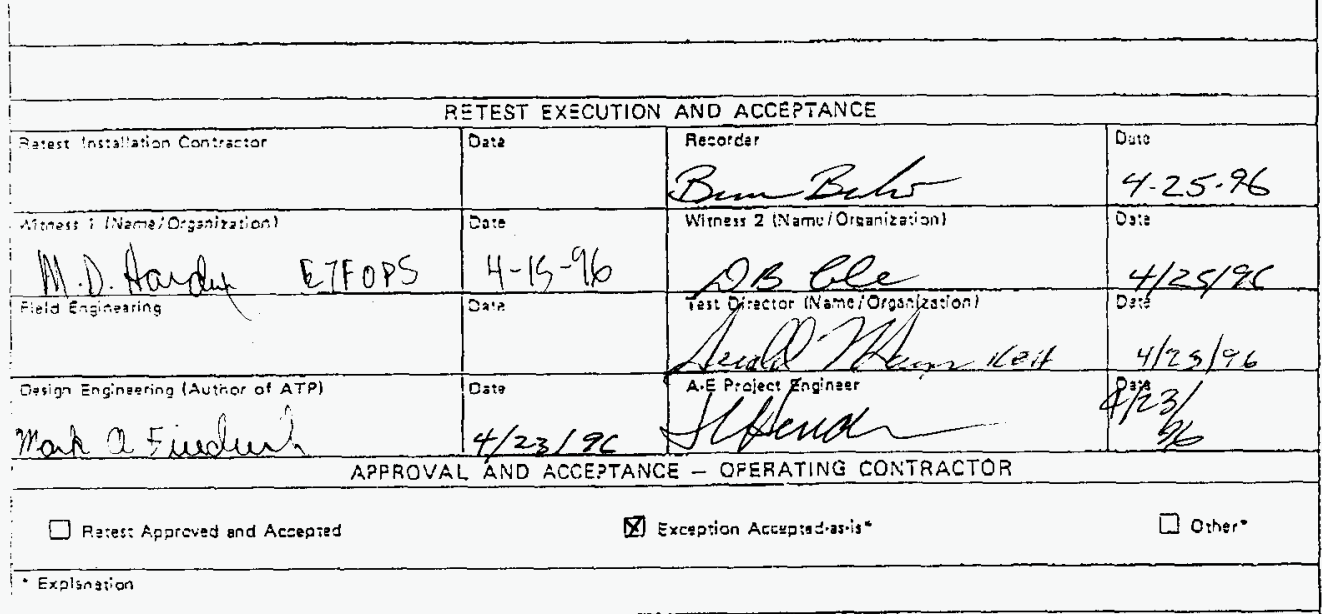

THE TEST OE THE MOTOR SIARTERS AZ-CW-P-IALB wIL BE CONDUCTED As PART OF THE PRE-OP TESTS.

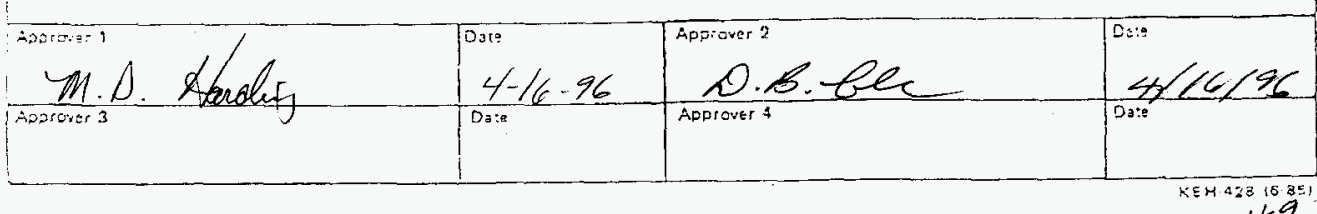

… II 